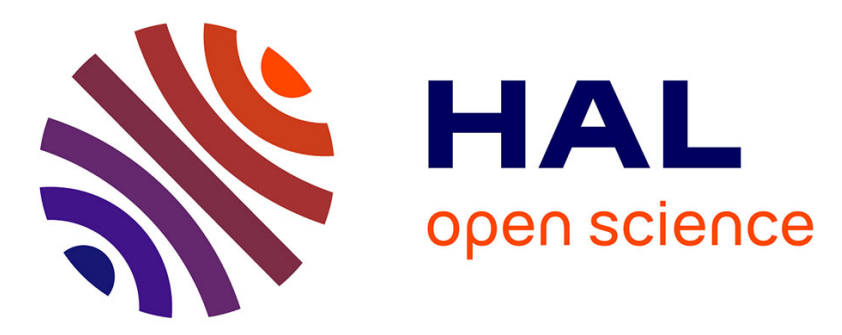

\title{
A 3-dimensional study of delta18O in atmospheric CO2: contribution of different land ecosystems
}

Philippe Peylin, Philippe Ciais, A. Scott Denning, Pieter Tans, Joseph Berry, James White

\section{- To cite this version:}

Philippe Peylin, Philippe Ciais, A. Scott Denning, Pieter Tans, Joseph Berry, et al.. A 3-dimensional study of delta18O in atmospheric CO2: contribution of different land ecosystems. Tellus B - Chemical and Physical Meteorology, 1999, 51 (3), pp.642-667. 10.1034/j.1600-0889.1999.t01-2-00006.x . hal02923872

\section{HAL Id: hal-02923872 \\ https://hal.science/hal-02923872}

Submitted on 29 Oct 2020

HAL is a multi-disciplinary open access archive for the deposit and dissemination of scientific research documents, whether they are published or not. The documents may come from teaching and research institutions in France or abroad, or from public or private research centers.
L'archive ouverte pluridisciplinaire HAL, est destinée au dépôt et à la diffusion de documents scientifiques de niveau recherche, publiés ou non, émanant des établissements d'enseignement et de recherche français ou étrangers, des laboratoires publics ou privés. 


\section{Tellus B: Chemical and Physical Meteorology}

\section{A 3-dimensional study of $\delta^{18} \mathrm{O}$ in atmospheric $\mathrm{CO}_{2}$ : contribution of different land ecosystems}

Philippe Peylin, Philippe Ciais, A. Scott Denning, Pieter P. Tans, Joseph A. Berry \& James W. C. White

To cite this article: Philippe Peylin, Philippe Ciais, A. Scott Denning, Pieter P. Tans, Joseph A. Berry \& James W. C. White (1999) A 3-dimensional study of $\delta^{18} \mathrm{O}$ in atmospheric $\mathrm{CO}_{2}$ : contribution of different land ecosystems, Tellus B: Chemical and Physical Meteorology, 51:3, 642-667, DOI: 10.3402/tellusb.v51i3.16452

To link to this article: https://doi.org/10.3402/tellusb.v51i3.16452

$$
\begin{aligned}
& \text { (c) } 1999 \text { The Author(s). Published by Taylor \& } \\
& \text { Francis. }
\end{aligned}
$$

曲 Published online: 15 Dec 2016.

Submit your article to this journal $\pi$

LII Article views: 48

Q View related articles ¿

4 Citing articles: 30 View citing articles $\asymp$ 


\title{
A 3-dimensional study of $\delta^{18} \mathrm{O}$ in atmospheric $\mathrm{CO}_{2}$ : contribution of different land ecosystems
}

\author{
By PHILIPPE PEYLIN*, PHILIPPE CIAIS ${ }^{1}$, A. SCOTT DENNING ${ }^{2}$, PIETER P. TANS ${ }^{3}$, JOSEPH \\ A. BERRY ${ }^{4}$ and JAMES W. C. WHITE ${ }^{5},{ }^{1} L S C E$, Laboratoire des Sciences du Climat et de \\ l'Environnement, Commisariat à l'Energie Atomique, l'Orme des Merisiers, Gif sur Yvette 91191, France; \\ ${ }^{2}$ Department of Atmospheric Science, Colorado State University, Fort Collins, CO 80523-1371, USA; \\ ${ }^{3}$ Climate Monitoring and Diagnostic Laboratory, NOAA, ERL 3, 325 Broadway, Boulder, CO 80303, USA; \\ ${ }^{4}$ Carnegie Institute of Washington, Department of Plant Biology, 290 Panama Street, Stanford, CA 94305, \\ USA; ${ }^{5}$ Institute of Arctic and Alpine Research and Department of Geological Sciences, University of \\ Colorado, Campus Box 450, Boulder, CO 80303, USA
}

(Manuscript received 23 January 1998; in final form 30 September 1998)

\begin{abstract}
Land biospheric carbon exchange associated with respiration and photosynthesis exerts a major control on the oxygen isotope composition $\left(\delta^{18} \mathrm{O}\right)$ of atmospheric $\mathrm{CO}_{2}$ especially with respect to the seasonal cycle. In particular, an important feature that requires our attention is the phase of the seasonal cycle of $\delta^{18} \mathrm{O}$ which lags $\mathrm{CO}_{2}$ by one month in the Arctic. We have developed a global parameterization of the land biotic exchange of ${ }^{18} \mathrm{O}$ in $\mathrm{CO}_{2}$, which has been prescribed in an atmospheric 3-D transport model in order to simulate the global atmospheric distribution of $\delta^{18} \mathrm{O}$. Furthermore, we have separated in the model the specific contribution of different regions of the globe to the seasonal and latitudinal variation of $\delta^{18} \mathrm{O}$. The model simulated values are compared in detail with atmospheric observations made at 22 different remote stations. The respective role of respiration vs. photosynthesis in determining the phase and amplitude of the $\delta^{18} \mathrm{O}$ seasonal cycle is also analyzed. Based on a good agreement between our model simulation and the atmospheric observations, we observe that the large seasonal cycle of $\delta^{18} \mathrm{O}$ at high latitudes is mainly due to the respiratory fluxes of all extra-tropical ecosystems while for $\mathrm{CO}_{2}$ the relative contributions of photosynthesis and respiration to the overall seasonal cycle are similar. Geographically, the $\mathrm{CO}_{2}$ exchanges with the northern Siberian ecosystem dominate the $\delta^{18} \mathrm{O}$ seasonality at all remote stations of the northern hemisphere, reflecting the strongly continental climate of that region.
\end{abstract}

\section{Introduction}

Carbon dioxide is the most important anthropogenic greenhouse gas and it has been increasing due to industrial activity and changes in land use from $280 \mathrm{ppm}$ in pre-industrial times up to $358 \mathrm{ppm}$ in 1995 . The terrestrial biosphere exerts a large influence on the atmospheric concentration

\footnotetext{
* Corresponding author.

Email: peylin@1sce.saclay.cea.fr
}

of $\mathrm{CO}_{2}$, as nearly $1 / 5$ of the atmospheric $\mathrm{CO}_{2}$ burden is exchanged annually with the vegetation through photosynthesis and total ecosystem respiration. The geographical patterns as well as the seasonal distribution of the $\mathrm{CO}_{2}$ gross fluxes associated with photosynthesis and respiration still remain to be better quantified.

Measurements of the stable isotopic composition of atmospheric $\mathrm{CO}_{2}$ provide additional information useful for clarifying these processes, although much of the previous work has focussed 
only on carbon isotopes (Keeling, 1958; Keeling et al., 1989; Ciais et al., 1995; Keeling et al., 1995; Francey et al., 1995). Recently, more attention has been paid to the ${ }^{18} \mathrm{O}$ isotope in atmospheric $\mathrm{CO}_{2}$ as it has the potential to distinguish photosynthesis from total ecosystem respiration, given the fact that $\mathrm{CO}_{2}$ emitted by these two processes has distinct isotopic signatures (Francey and Tans, 1987; Farquhar et al., 1993; Flanagan and Varney, 1995). The NOAA (National Oceanic and Atmospheric Administration), the Scripps-CIO (Centrum voor Isotopen Onderzoek) and the CSIRO (Commonwealth Scientific and Industrial Research Organisation) global air sampling networks routinely measure at various locations the $18 \mathrm{O}$ content in atmospheric $\mathrm{CO}_{2}$, hereafter expressed in $\delta$ units:

$\delta^{18} \mathrm{O}=\left(\frac{\left({ }^{18} \mathrm{O} /{ }^{16} \mathrm{O}\right)}{\left({ }^{18} \mathrm{O} /{ }^{16} \mathrm{O}\right)_{\mathrm{PDB}-\mathrm{CO}_{2}}}-1\right) 10^{3}$

(symbols are defined in Appendix). The $\delta^{18} \mathrm{O}$ measurements show the following: (1) a large seasonal cycle at high northern latitudes with a maximum in early summer and a minimum in early winter, (2) a permanent annual mean Arctic minus Antarctic difference of roughly $-1.5 \%$ and (3) a global average growth rate of approximately zero.

Francey and Tans (1987) and Farquhar et al. (1993) have described the mechanisms by which the terrestrial biosphere exerts a major influence on the $\delta^{18} \mathrm{O}$ of atmospheric $\mathrm{CO}_{2}$ through the processes of photosynthesis and total respiration. Ciais et al. (1997b) have further simulated the global monthly $\delta^{18} \mathrm{O}$ distribution using a threedimensional atmospheric tracer Model, which reproduces reasonably well the main characteristics of the observations mentioned above.

In this paper, we analyze in more detail the observed and modeled seasonal cycle of atmospheric $\delta^{18} \mathrm{O}$ at specific locations around the world, as well as the specific contribution of different terrestrial ecosystems using the same transport model as Ciais et al. (1997b). Namely, we have modeled the $\delta^{18} \mathrm{O}$ emitted independently by 16 different regions. These 16 tracers sum up to the overall biospheric component of $\delta^{18} \mathrm{O}$ in $\mathrm{CO}_{2}$. In addition, for each region photosynthesis and respiration are treated separately in the model. This "tagging" approach is motivated by the two following reasons: First, separating explicitly photosynthesis from respiration in the model is expected to produce information on the relative importance of these two processes. Of particular interest is the convolution between the $\mathrm{CO}_{2}$ fluxes and their isotopic signature which is controlled by the hydrological cycle and by ecological factors (Farquhar et al., 1993). Second, as $\mathrm{CO}_{2}$ fluxes and isotopic signatures differ between ecosystems, the relative contribution of selected eco-regions to the $\delta^{18} \mathrm{O}$ seasonal cycle at remote background locations and to the meridional profile are very different.

\section{3-D model of $\delta^{18} \mathrm{O}$ in atmospheric $\mathrm{CO}_{2}$}

The variations of $\delta^{18} \mathrm{O}$ in atmospheric $\mathrm{CO}_{2}$, hereafter expressed in per mil (\%) relative to PDB$\mathrm{CO}_{2}$ are to a large extent determined by the $\delta^{18} \mathrm{O}$ of specific reservoirs of liquid water. When $\mathrm{CO}_{2}$ dissolves in water, a heavy oxygen atom may exchange with $\mathrm{H}_{2} \mathrm{O}$ upon hydration of the $\mathrm{CO}_{2}$ (eq. (A1) in Section 7). Although the reaction is slow, thus preventing exchange between cloud water and $\mathrm{CO}_{2}$ in the atmosphere, quick isotopic equilibrium is reached within chloroplasts in leaves during photosynthesis due to the presence of the enzyme carbonic anhydrase. Soil respired $\mathrm{CO}_{2}$ also reacts isotopically with soil moisture.

- Photosynthesis. During photosynthesis, a large fraction of the $\mathrm{CO}_{2}$ which diffuses into the chloroplast is not incorporated into plant assimilates but rather diffuses back into the atmosphere. The retrodiffused flux depends on the partial pressure of $\mathrm{CO}_{2}$ in the chloroplast where it will have equilibrated isotopically with chloroplast water. Isotopic equilibrium (eq. (A1)) occurs in spite of the short residence time of $\mathrm{CO}_{2}$ in the leaf because of the presence of the enzyme carbonic anhydrase, which dramatically speeds up the hydration of $\mathrm{CO}_{2}$ (Reed and Graham, 1981). Chloroplast water is enriched in ${ }^{18} \mathrm{O}$ mostly because heavier water molecules evaporate less efficiently and more slowly than lighter ones. The degree of enrichment of leaf water depends on the relative humidity at the leaf surface, the leaf temperature and the $\delta^{18} \mathrm{O}$ of water vapor outside of the leaf according to the Craig and Gordon (1965) steady state formulation (eq. (A2)).

- Ecosystem respiration. $\mathrm{CO}_{2}$ is emitted to the 
atmosphere by the decomposition of dead organic matter and by respiring roots within the soil profile, as well as by stems and twigs aboveground. Leaf respiration is associated with leaf $\delta^{18} \mathrm{O}$ and subtracted from assimilation. In absence of net carbon storage or loss in a given ecosystem, the annual respiration is equal to the annual $\mathrm{CO}_{2}$ assimilation (gross primary production, GPP). Below-ground respired $\mathrm{CO}_{2}$ is considered to be in most cases in isotopic equilibrium with soil moisture of only the upper $5-10 \mathrm{~cm}$ of the soil (Tans, 1998). The stems and twigs respiration should reflect the $\delta^{18} \mathrm{O}$ water content of the root soil layer but we do not parameterize it separately in the model.

The $\delta^{18} \mathrm{O}$ of $\mathrm{CO}_{2}$ retrodiffused by the leaves (respectively emitted by the soils) depends thus on three factors: (1) the $\delta^{18} \mathrm{O}$ of chloroplast water (surface soil moisture), (2) the leaf (soil) temperature which influences the isotopic equilibrium between $\mathrm{CO}_{2}$ and $\mathrm{H}_{2} \mathrm{O}$ (eq. (A1)), and (3) the kinetic fractionation during $\mathrm{CO}_{2}$ diffusion out of the leaves (soils).

- Other processes. The exchange of $\mathrm{CO}_{2}$ with the oceans, the release of $\mathrm{CO}_{2}$ due to fossil fuels and biomass burning, as well as the enrichment of ${ }^{18} \mathrm{O}$ in stratospheric $\mathrm{CO}_{2}$ relative to the mean tropospheric value (Thiemens and Jackson, 1991), do not strongly impact the $\delta^{18} \mathrm{O}$ seasonal cycle (Ciais et al., 1997b), although they contribute to the latitudinal gradient.

All surface processes are modeled as in Ciais et al. (1997a) and the stratospheric enrichment is parameterized as in Peylin et al. (1996). We use for $\mathrm{CO}_{2}$ fluxes, relative humidity, leaf temperature and soil temperature the global fields of the $\mathrm{SiB} 2$ land-surface parameterization (Sellers et al., 1996a, b) coupled to the CSU GCM (Randall et al., 1996). The monthly isotopic composition of worldwide water vapor and meteoric water from which is derived the $\delta^{18} \mathrm{O}$ of soil moisture are taken from the GISS GCM (Jouzel et al., 1987). We then prescribed the $\delta^{18} \mathrm{O}$ and $\mathrm{CO}_{2}$ fluxes in the atmospheric tracer model TM2 (Heimann, 1995).

In the ${ }^{18} \mathrm{O}$ budget of atmospheric $\mathrm{CO}_{2}$, resulting from all processes mentioned above (eq. (A3)), photosynthesis and ecosystem respiration generally have opposing effects. Whereas photosynthesis enriches atmospheric $\mathrm{CO}_{2}$ in ${ }^{18} \mathrm{O}$, respiration depletes it. The seasonal variations of these two processes thus induce a pronounced seasonal cycle in atmospheric $\delta^{18} \mathrm{O}$, whose peak-to-peak amplitude depends, among other variables, on the isotopic fractionation of $\mathrm{CO}_{2}$ retrodiffused by the leaves and emitted by soil respiration (kinetic fractionation factors $\varepsilon_{1}$ and $\varepsilon_{\mathrm{s}}$, respectively, eq. (A3)). Peylin et al. (1996) have shown that the $\delta^{18} \mathrm{O}$ seasonal amplitude is strongly sensitive to both $\varepsilon_{1}$ and $\varepsilon_{\mathrm{s}}$. A value of $-8.8 \%$ for these coefficients corresponds to pure molecular diffusion (based on the relative masses of $\mathrm{CO}_{2}$ and air). Farquhar et al. (1993) have recommended a value of $-7.4 \%$ for the combined effects of diffusion from the free atmosphere to the site of carboxylation in the chloroplast; we adopted their value for $\varepsilon_{1}$. In the case of soil respired $\mathrm{CO}_{2}$, we use the value of $-8.8 \%$ or $\varepsilon_{\mathrm{s}}$ which gives the best agreement between observed and modeled $\delta^{18} \mathrm{O}$ seasonal amplitude at high latitudes (Peylin et al., 1996). This does not take into account that if $\mathrm{CO}_{2}$ production occurs near the soil surface, the value of $\varepsilon_{\mathrm{s}}$ may be lower due to competing exchange with soil moisture (Hesterberg and Siegenthaler, 1991 ), and that water in top of soil profile is often enriched in ${ }^{18} \mathrm{O}$ (Mathieu and Bariac, 1996). Nevertheless using higher values of $\varepsilon_{\mathrm{s}}$ for all ecosystems will not change the basic results derived in this paper.

The resulting simulated global $\delta^{18} \mathrm{O}$ 3-D fields are expressed in $\delta$-anomalies (Heimann and Keeling, 1989). $\delta$-anomalies are constructed as additive quantities measuring the incremental change of "background" $\delta^{18} \mathrm{O}$ in atmospheric $\mathrm{CO}_{2}$ $\left(\delta_{\mathrm{bg}}\right)$ corresponding to an incremental change in $\mathrm{CO}_{2}$ concentration. For process number $i$ involving a concentration change $C_{i}$ :

$\delta_{i}$-anomaly $=\frac{C_{i}\left(\delta_{i}-\delta_{\mathrm{bg}}\right)}{\sum_{\mathrm{i}} C_{i}}$

(symbols defined in Section 7). This notation allows direct addition of the relative contribution of each component to the overall $\delta^{18} \mathrm{O}$ signal.

- Atmospheric transport model. The TM2 model, described in Heimann (1995) is a 3-D offline atmospheric tracer model driven by meteorological fields derived from analyses of the European Center for Medium Range Weather Forecast (ECMWF) on a 12-h basis. Vertical convective transport is computed at all levels using the scheme of Tiedke (1989) and turbulent vertical 
transport is calculated from Louis (1979). The model resolution is $7.5^{\circ}$ by $7.5^{\circ}$ in the horizontal, with nine vertical levels (sigma coordinates) and a time step of $3 \mathrm{~h}$. We ran the TM2 model for 6 years repeatedly prescribing the transport fields of year 1990 over the first four years and then following up with the 1991 and 1992 transport fields. As the $\mathrm{CO}_{2}$ concentration gradients are spun up for 3 years to reach steady state, we averaged the simulated fields over the last three years of the simulation to minimize year to year variation in the modeled atmospheric concentrations.

\section{Study of the $\delta^{18} \mathrm{O}$ signal at remote background locations}

\subsection{Analysis of the atmospheric $\delta^{18} \mathrm{O}$ measurements}

Measurements of $\delta^{18} \mathrm{O}$ in atmospheric $\mathrm{CO}_{2}$ are from flask samples collected at remote background locations (referred by a 3-letter code in Table 1) by 3 independent air sampling networks. At midand high- northern latitudes, we use the isotopic measurements of the National Oceanic and Atmospheric Administration and the University of Colorado (NOAA-CU) network conducted since 1990. These data come from 16 sites and are presented in Trolier et al. (1995). In the tropics, we use the data of the Scripps Institution for Oceanography jointly with the Centrum voor Isotopen Onderzoek (Scripps-CIO) network, where isotopic measurements were initiated in 1977 (a full report of the Scripps-CIO data is in preparation (private communication $\mathrm{H}$. Meijer) and some data can be seen in Ciais and Meijer (1998)). Neither NOAA-CU or Scripps-CIO dry the air prior to storage in the flask. Whereas for NOAA-CU, the $\delta^{18} \mathrm{O}$ of atmospheric $\mathrm{CO}_{2}$ collected at humid tropical locations is occasionally contaminated by exchange of oxygen atoms between $\mathrm{CO}_{2}$ and water condensed on the flask walls (Gemery et al., 1996), the Scripps-CIO samples appear to record more faithfully the $\delta^{18} \mathrm{O}$ of atmospheric $\mathrm{CO}_{2}$. The reasons are unclear but we can note that the Scripps-CIO used larger flasks ( 5 liter compared to 2 liter for NOAA-CU) with thus a larger surface-to-volume ratio, which might decrease the amount of water condensed on the flask wall. Nevertheless recent dry data from NOAA-CU at SMO show a large bias compared to the wet data (Rasmussen, 1996) and these latter tend to be consistently more depleted in ${ }^{18} \mathrm{O}$. We should thus be cautious in comparing model outputs and data over the Tropics. We also use the data of the CSIRO Division of Atmospheric Research at CGO and SPO stations (Francey et al., 1990). The CSIRO sampling strategy involves drying of the air resulting in better experimental precision on $\delta^{18} \mathrm{O}$ analysis. The CGO and SPO records provide 10 -year time series which better define the small seasonality in the southern extra-tropics.

We have fitted the flask data with curves containing a second-order polynomial term and four annual harmonics (Thoning et al., 1994). Deviations of individual flask measurements from this fit (residuals) are then filtered in the time domain using a low pass filter of full width at half maximum of 40 days and added back to the initially fitted function. This results in a so called "smoothed time series" where short term fluctuations in $\delta^{18} \mathrm{O}$ have been partially eliminated, while long term ones (seasonal and year to year variations for instance) are preserved. At high southern latitudes (CGO and SPO), year to year variations in $\delta^{18} \mathrm{O}$ are of approximately the same magnitude as the amplitude of the mean seasonal cycle. We thus fit the data using only four harmonics to describe the mean seasonal cycle at these two stations. An average seasonal curve (one year) is then constructed from the total "smoothed time series". We also compute for each station the standard deviation of all residuals between flask measurements and the "smoothed time series as an estimation of a mean error bar. The standard deviations defined in that manner are fairly large ( $\sim 0.4 \%$ ond $\sim 0.7 \%$ o for high and mid northern latitudes respectively), mainly because isotopic exchange with $\mathrm{H}_{2} \mathrm{O}$ in flask increases the errors.

\subsection{Relative contribution of the biosphere exchanges: photosynthesis versus respiration}

Our modeling combines several data that are on different grids and different time steps. This requires an averaging process where monthly fluxes maps are finally assembled. Furthermore monthly fluxes are injected uniformly every month into the TM2 model which reads the transport every $12 \mathrm{~h}$ and calculates the concentration fields 
Table 1. Code used in the text, name, latitude, longitude, sigma level in TM2 $(\sigma)$, available years of measured $\delta^{18} \mathrm{O}$ in atmospheric $\mathrm{CO}_{2}$, peak to peak amplitude (in \%o $\mathrm{PDB}-\mathrm{CO}_{2}$ ) and position of the maximum and minimum ( $x_{\max }$ and $x_{\min }$ respectively, in number of weeks from the beginning of January) of the mean $\delta^{18} \mathrm{O}$ seasonal cycle, for all stations used to compare the seasonality between model and data

\begin{tabular}{|c|c|c|c|c|c|c|c|c|}
\hline Code & Station & Lat. & Long. & $\sigma$ & $\begin{array}{l}\text { Years } \\
\text { obs }\end{array}$ & $\begin{array}{c}\delta^{18} \text { Ampli. } \\
\text { obs/mod }\end{array}$ & $\begin{array}{l}\delta^{18} x_{\max } \\
\text { obs/mod }\end{array}$ & $\begin{array}{l}\delta^{18} x_{\min } \\
\text { obs } / \text { mod }\end{array}$ \\
\hline ALT & Alert, Canada ${ }^{\text {a) }}$ & $82.3^{\circ} \mathrm{N}$ & $62.3^{\circ} \mathrm{W}$ & 1 & $92-95$ & $1.20 / 1.06$ & $15 / 21$ & $35 / 37$ \\
\hline MBC & Mould Bay, Canada $^{\text {a) }}$ & $76.1^{\circ} \mathrm{N}$ & $119.2^{\circ} \mathrm{W}$ & 1 & $92-94$ & $1.47 / 1.14$ & 16.21 & $36 / 37$ \\
\hline BRW & Barrow, Alaska ${ }^{\text {a) }}$ & $71.2^{\circ} \mathrm{N}$ & $156.4^{\circ} \mathrm{W}$ & 1 & $90-95$ & $1.26 / 1.11$ & $17 / 20$ & $39 / 36$ \\
\hline STM & Station "M"a) & $66.0^{\circ} \mathrm{N}$ & $2.0^{\circ} \mathrm{E}$ & 1 & $94-95$ & $1.06 / 0.94$ & $21 / 22$ & $39 / 36$ \\
\hline ICE & Iceland $^{\text {a) }}$ & $63.1^{\circ} \mathrm{N}$ & $20.1^{\circ} \mathrm{W}$ & 1 & $92-95$ & $1.07 / 0.94$ & $22 / 22$ & $38 / 35$ \\
\hline MHT & Mace Head, Ireland ${ }^{\text {a) }}$ & $53.2^{\circ} \mathrm{N}$ & $9.5^{\circ} \mathrm{W}$ & 1 & $91-95$ & $1.11 / 0.86$ & $24 / 22$ & $39 / 37$ \\
\hline CBA & Cold Bay, Alaska ${ }^{\text {a) }}$ & $55.1^{\circ} \mathrm{N}$ & $162.4^{\circ} \mathrm{W}$ & 1 & $92-95$ & $1.29 / 1.11$ & $25 / 20$ & $36 / 35$ \\
\hline BAL & Baltic Sea ${ }^{a}$ & $55.3^{\circ} \mathrm{N}$ & $16.4^{\circ} \mathrm{E}$ & 1 & $92-95$ & $1.51 / 1.28$ & $18 / 22$ & $38 / 35$ \\
\hline SHM & Shemya Island ${ }^{a)}$ & $52.4^{\circ} \mathrm{N}$ & $174.1^{\circ} \mathrm{E}$ & 1 & $92-95$ & $1.50 / 1.31$ & $24 / 15$ & $35 / 34$ \\
\hline HUN & Hegyhatsal, Hungarya) & $46.6^{\circ} \mathrm{N}$ & $16.2^{\circ} \mathrm{E}$ & 1 & $93-95$ & $2.40 / 1.42$ & $21 / 22$ & $42 / 33$ \\
\hline BRN & Bern, Switzerland & $46.9^{\circ} \mathrm{N}$ & $7.5^{\circ} \mathrm{E}$ & 1 & $88-89$ & $2.50 / 0.91$ & $20 / 24$ & $01 / 34$ \\
\hline $\mathrm{CMO}$ & Cape Meares, Oregon ${ }^{a)}$ & $45.3^{\circ} \mathrm{N}$ & $123.6^{\circ} \mathrm{W}$ & 1 & $92-95$ & $0.87 / 0.83$ & $23 / 16$ & $34 / 35$ \\
\hline NWR & Niwot Ridge, Colorado ${ }^{\text {a) }}$ & $40.0^{\circ} \mathrm{N}$ & $105.4^{\circ} \mathrm{W}$ & 3 & $92-95$ & $1.04 / 0.46$ & $24 / 19$ & $42 / 38$ \\
\hline UUM & Ulaan Uul, Mongolia ${ }^{\text {a) }}$ & $44.3^{\circ} \mathrm{N}$ & $111.1^{\circ} \mathrm{E}$ & 1 & $92-95$ & $1.45 / 1.64$ & $23 / 15$ & $43 / 32$ \\
\hline QPC & Qinghai Province, China ${ }^{\text {a) }}$ & $36.2^{\circ} \mathrm{N}$ & $100.6^{\circ} \mathrm{E}$ & 1 & $90-95$ & $0.88 / 0.83$ & $23 / 14$ & $39 / 33$ \\
\hline TAP & Tae-ahn, Korea ${ }^{\text {a) }}$ & $36.4^{\circ} \mathrm{N}$ & $126.1^{\circ} \mathrm{E}$ & 1 & $90-95$ & $1.61 / 1.05$ & $19 / 14$ & $30 / 36$ \\
\hline LJO & La-Jollab) & $32.9^{\circ} \mathrm{N}$ & $117.3^{\circ} \mathrm{W}$ & 1 & $78-88$ & $0.79 / 0.56$ & $24 / 17$ & $44 / 39$ \\
\hline IZO & Isana Obs., Tenerife ${ }^{a)}$ & $28.2^{\circ} \mathrm{N}$ & $16.3^{\circ} \mathrm{W}$ & 1 & $91-95$ & $0.68 / 0.62$ & $20 / 20$ & $48 / 40$ \\
\hline MLO & Mauna Loa, Hawaii b) & $19.3^{\circ} \mathrm{N}$ & $155.3^{\circ} \mathrm{W}$ & 4 & $86-89$ & $0.44 / 0.29$ & $21 / 27$ & $40 / 39$ \\
\hline KUM & Cape Kumukahi, Hawaii ${ }^{\text {b) }}$ & $19.3^{\circ} \mathrm{N}$ & $154.5^{\circ} \mathrm{W}$ & 1 & $84-89$ & $0.72 / 0.42$ & $24 / 18$ & $41 / 37$ \\
\hline CGO & Cape Grim, Tasmania ${ }^{c)}$ & $40.4^{\circ} \mathrm{S}$ & $144.4^{\circ} \mathrm{E}$ & 1 & $82-91$ & $0.21 / 0.25$ & $4 / 44$ & $24 / 20$ \\
\hline SPO & South Pole, Antarctica ${ }^{\text {) }}$ & $89.6^{\circ} \mathrm{S}$ & $24.5^{\circ} \mathrm{W}$ & 1 & $83-96$ & $0.22 / 0.28$ & $11 / 4$ & $20 / 25$ \\
\hline
\end{tabular}

a), b), c) For NOAA-CU, Scripps-CIO, CSIRO networks, respectively.

every three hours. We thus miss important features of the ${ }^{18} \mathrm{O}$ cycle, the diurnal cycle (Flanagan and Varney, 1995; Bariac, 1988) and the subsequent short term variations in the soil/leaf isotopic exchanges. Eventually, this study needs to be repeated with a fully coupled model where all variables are computed with the same time basis and with wind fields that correspond to the period covered by the data. Yet, because we use mostly data at remote sites far from immediate vicinity of sources and because the atmospheric transport has a strong smoothing effect, our model still enables us to capture the seasonal and annual variation in $\mathrm{CO}_{2}$ and $\delta^{18} \mathrm{O}$. Given the low horizontal resolution of the model, we archive the model concentrations at the exact position of each station within its grid cell using a bilinear interpolation. A mean seasonal cycle is then calculated from the resulting model time series ( 3 years) using the same procedure as the one described for the observations. At CGO however, we have sampled the model concentrations at the center of one grid box to the South-West of the grid box containing CGO in order to account for the fact that flask data for coastal stations are collected only under windy conditions when the wind comes from the ocean. For other coastal stations like BRW and LJO we do not change grid cell as the position of these stations is already located at the border of a grid cell close to the next oceanic grid cell. The interpolation will thus partly account for this effect and we also did not find any significant difference between the two adjacent grid cell, especially for $\delta^{18} \mathrm{O}$.

The ability of the model to simulate realistic $\delta^{18} \mathrm{O}$ values relies first on its ability to perform well for the $\mathrm{CO}_{2}$ concentrations themselves. To check this, we compare at a few stations the modeled $\mathrm{CO}_{2}$ seasonal cycle with the observations (Fig. 1). The overall simulated values reproduce fairly well the seasonal minimum and maximum in concentration. Nevertheless, at BRW the 

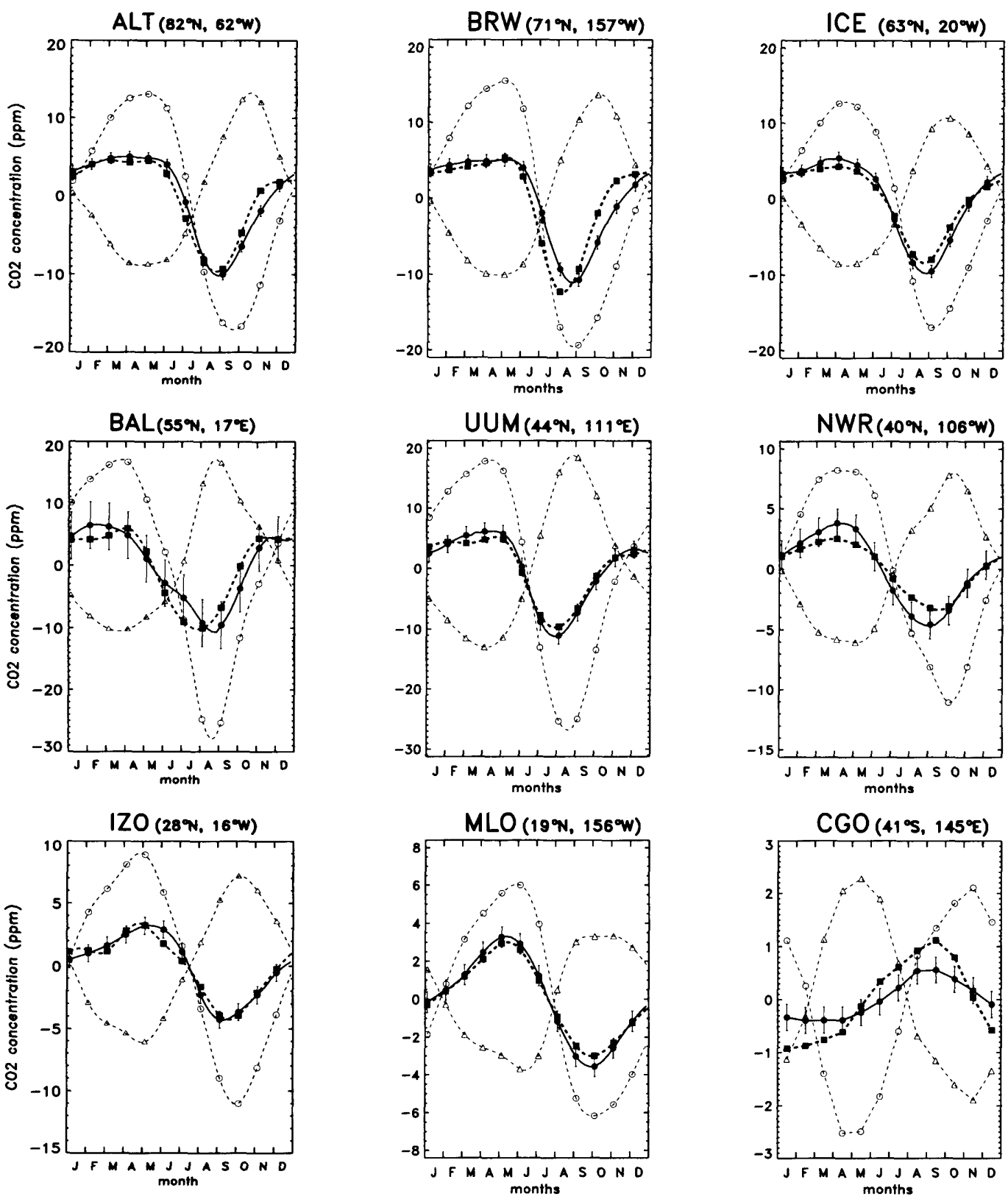

Fig. 1. Mean seasonal cycle of atmospheric $\mathrm{CO}_{2}$ concentration, simulated by the TM2 model at a few stations (dashed line) compared with the observations (solid line with circles). Curve with plain squares represents the overall modeled $\mathrm{CO}_{2}$ concentration including all processes. Curves with circles and triangles separate the exchange of $\mathrm{CO}_{2}$ due only to photosynthesis and respiration, respectively. All curves have been detrended separately as described in Subsection 3.1. (Increase of the photosynthetic curve during winter-time comes only from the detrending process; same for the decrease of the respiration curve.) Error bars on the observations represent \pm the standard deviation of all residuals between flask data and the fitted curve. 
simulated minimum precedes the observed one by approximately one month (also at ALT). Soil temperature simulated by $\mathrm{SiB} 2$ is colder than observed at high northern latitudes in winter under snow-pack, so annually balanced respiration is delayed. This tends to produce early drawdown of $\mathrm{CO}_{2}$ in the model (Denning et al., 1996). At NWR, the model underestimates the peak to peak amplitude of the observations by one third. As the mean altitude of the model in the grid cell of NWR is only $\sim 1700 \mathrm{~m}$ compared to the altitude of the site $(3750 \mathrm{~m})$, we placed NWR at the third level from the surface. Placing this station at the surface enhances the amplitude of the modeled $\mathrm{CO}_{2}$ seasonal cycle but on the other hand it changes the phase in disagreement with the observations. This case points out the difficulty of using high altitude continental stations in a model with coarse horizontal and vertical resolutions. At CGO, the simulated amplitude overestimates the observed one by a factor of two. This discrepancy results partly from a too large seasonal amplitude associated with the oceanic exchange of $\mathrm{CO}_{2}$ and partly from the crude data selection criteria used in the model (as described above). In the following, we will discuss in more detail the model $\delta^{18} \mathrm{O}$ seasonal cycle and the relative contributions of the biotic exchanges.

- High northern latitudes stations (north of $55^{\circ} \mathrm{N}$ ). The TM2 model driven by the SiB2 biospheric $\mathrm{CO}_{2}$ fluxes performs fairly well both for the peak to peak amplitude and for the phase of the $\delta^{18} \mathrm{O}$ annual cycle (Fig. 2). The simulated values usually fall within the range of variability of the observations (except at BRW in summer and at SHM in July). Yet, some discrepancies exist between model and data. The simulated maximum at ALT, MBC, and BRW slightly lags the observed one (nearly 1 month, Table 1 ) while at CBA and SHM the model does not produce a peak in $\delta^{18} \mathrm{O}$ during July. The timing of the simulated minimum corresponds closely with the observations. For $\delta^{18} \mathrm{O}$ at high northern latitudes, the ecosystem respiration (dashed curves with triangles) appears clearly as the dominant process controlling the overall $\delta^{18} \mathrm{O}$ seasonality. In particular, the sharp decrease of $\delta^{18} \mathrm{O}$ during the summer reflects essentially the isotopic signature of respired $\mathrm{CO}_{2}$ whereas leaf retrodiffused $\mathrm{CO}_{2}$ would result in only a small change in the opposite direction. North of $50^{\circ} \mathrm{N}$, respiration emits a large amount of $\mathrm{CO}_{2}$ in summer depleted in ${ }^{18} \mathrm{O}$ by on average $15 \%$ compared to the mean atmospheric value. For $\mathrm{CO}_{2}$ only, on the other hand, the relative contributions of photosynthesis and respiration to the overall seasonal cycle are similar (Fig. 1). Unlike $\delta^{18} \mathrm{O}$, for $\mathrm{CO}_{2}$ the concentration decreases from June to August because the uptake of $\mathrm{CO}_{2}$ by photosynthesis is larger than the release by respiration.

- Mid northern latitude stations (between $35^{\circ} \mathrm{N}$ and $55^{\circ} \mathrm{N}$ ). The model reproduces reasonably well the pattern of $\delta^{18} \mathrm{O}$, including at continental locations (Fig. 3). However, the agreement is not as good as for high latitudes stations, although the estimates of variability in the data are relatively large. Among the discrepancies between model and data, the simulated $\delta^{18} \mathrm{O}$ minimum precedes the observations by up to two months at HUN, BRN, QPC, and UUM and the simulated maximum also precedes the observed one at UUM, TAP, CMO, and NWR by approximately one month (Table 1). The overall model peak to peak amplitude is too low at HUN, BRN, and NWR by respectively $41 \%, 60 \%$, and $55 \%$. These differences between model and observations may be attributed to various factors. Five mid-latitudes stations out of eight are located in the interior of the continents, in the proximity of intense biospheric exchange and occasionally close to industrial areas (BRN, HUN, and TAP). As the horizontal resolution of the model is only of $7.5^{\circ}(800 \mathrm{~km}$ at the equator), sub-grid scale concentration differences reflecting local fossil fuels $\mathrm{CO}_{2}$ emissions or different onset of the growing season are not resolved. In the case of HUN and BRN, and low $\delta^{18} \mathrm{O}$ values observed in winter probably reflect the occurrence of local anthropogenic emissions of $\mathrm{CO}_{2}$ characterized by low $\delta^{18} \mathrm{O}(-17 \%)$ together with very stable atmospheric conditions in the lower atmosphere. A study by Haszpra (1995) reports for HUN that during winter an occasionally very stable boundary layer forms in the Carpathian Basin reducing vertical mixing which leads to the accumulation of gases emitted at the surface. Unlike at high latitude stations (Fig. 2), photosynthesis contributes as much as respiration to the $\delta^{18} \mathrm{O}$ seasonal cycle at $\mathrm{BAL}$, HUN, BRN, and QPC.

- Tropical and sub-tropical stations. The agreement between modeled and observations is satisfactory, given the large variability associated with 

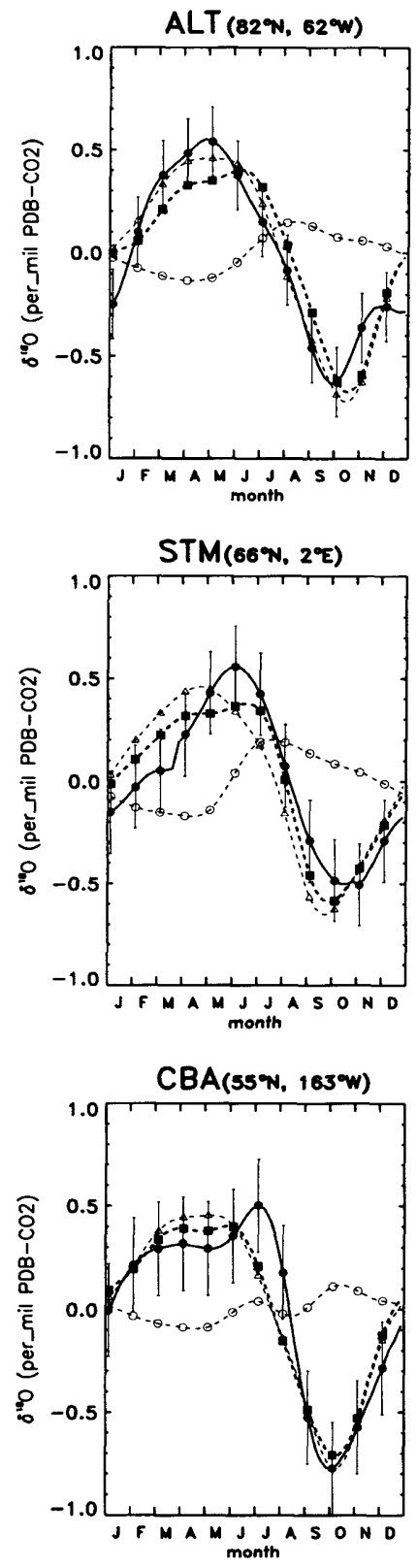
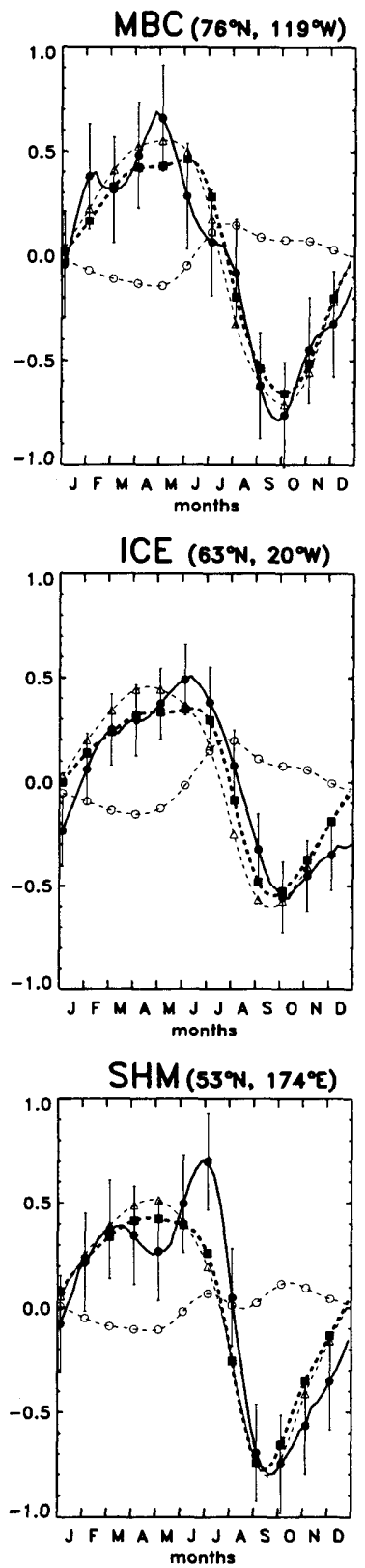
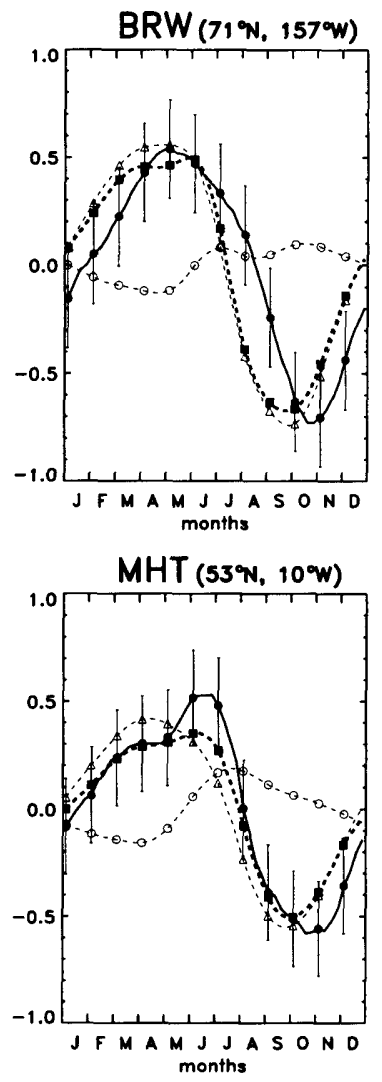

Fig. 2. As Fig. 1, but for $\delta^{18} \mathrm{O}$ in atmospheric $\mathrm{CO}_{2}$ at high northern latitude stations.

the measurements (Fig. 4). The simulated $\delta^{18} \mathrm{O}$ seasonal cycles at LJO, IZO, MLO, and KUM are approximately in phase with the observations. At LJO, MLO, and KUM the modeled annual cycle is too low in amplitude by respectively $29 \%$,
$34 \%$, and $42 \%$. These discrepancies between model and data are not observed for the $\mathrm{CO}_{2}$ concentration (IZO and MLO, Fig. 1). Note that the higher amplitude observed at KUM compared to MLO reflects the difference in elevation 

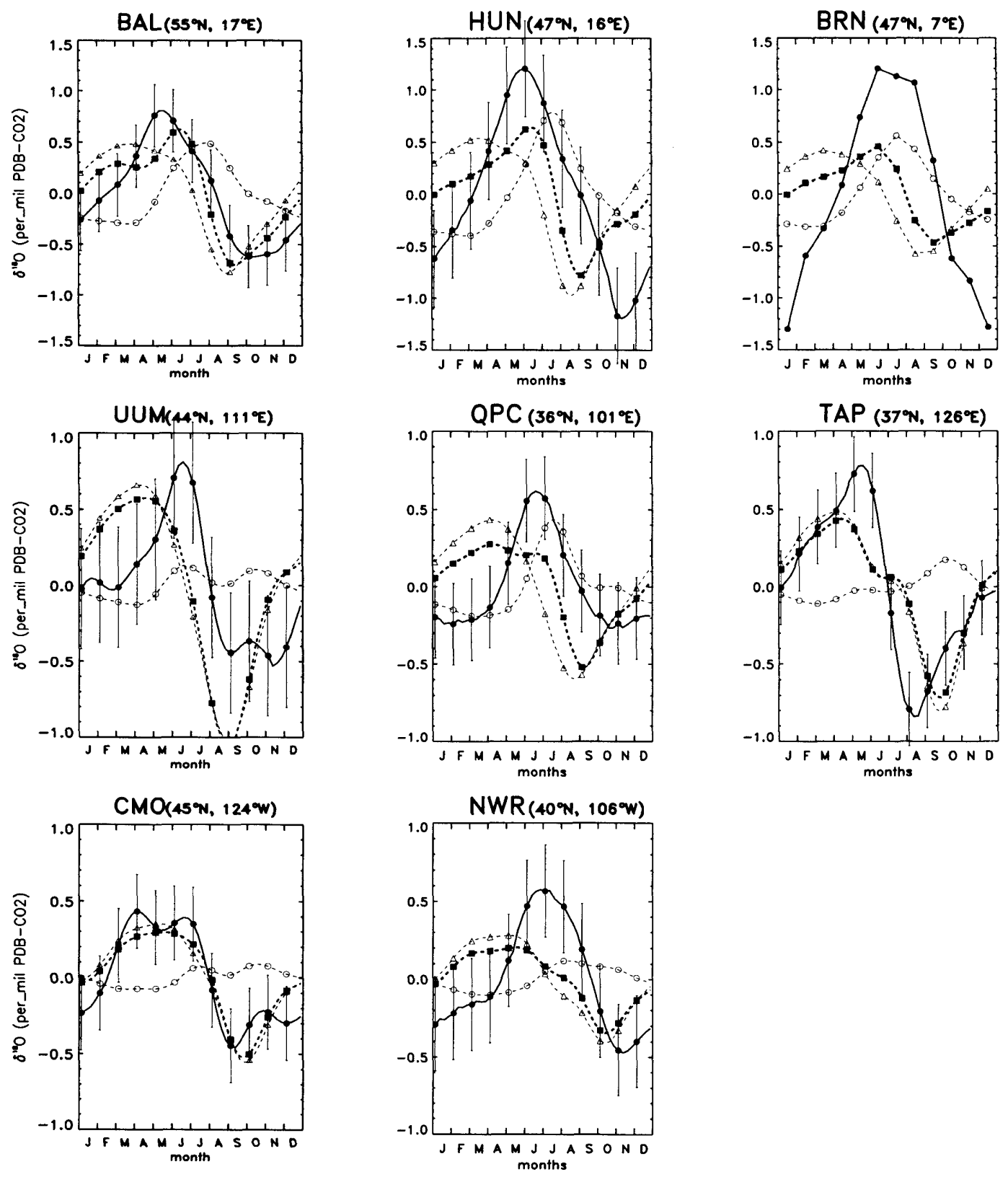

Fig. 3. As Fig. 2, but for stations located at mid latitudes of the northern hemisphere. For BRN we do not have error bars as only one year of records is available.

between these stations. MLO samples air at $3400 \mathrm{~m}$ (sigma level 4 in the TM2 model) and seasonal variations originating at the Earth's surface are smoothed at this altitude. As at high northern latitudes stations, respiration is the dominant process that controls the overall $\delta^{18} \mathrm{O}$ seasonal cycle.

- Southern hemisphere. The simulated $\delta^{18} \mathrm{O}$ 

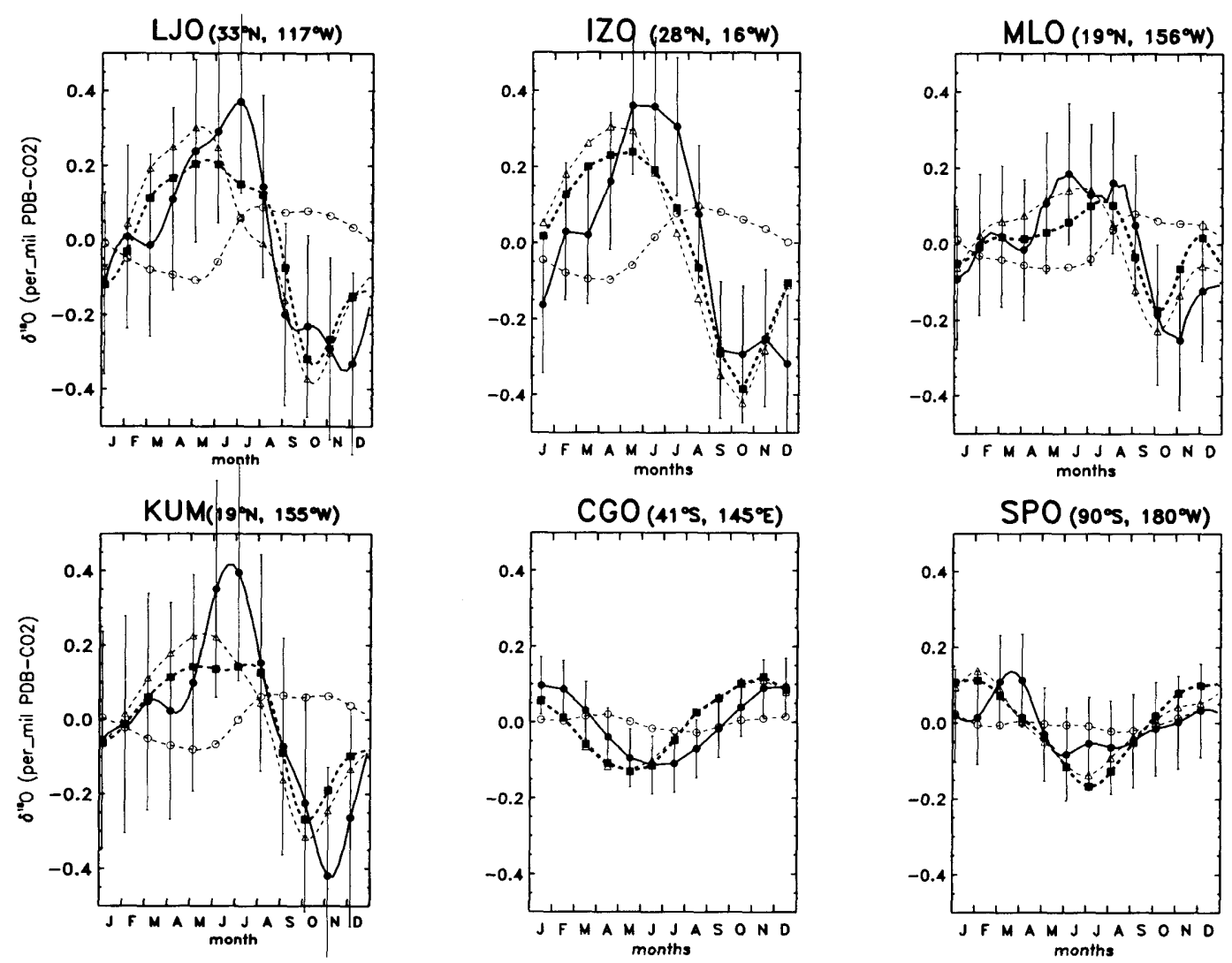

Fig. 4. As Fig. 2, but for stations located in the tropics, subtropics, and in the southern hemisphere.

peak-to-peak amplitude at CGO agrees reasonably well with the data, but the phase of the minimum occurs three months earlier in the model. At SPO, the data indicate a large seasonal variation of $0.2 \%$, i.e. roughly $20 \%$ of the peak to peak amplitude at high northern latitudes sites. In comparison, the seasonal cycle of $\mathrm{CO}_{2}$ at SPO is only $\sim 8 \%$ of the seasonal cycle at high northern latitudes. The ecosystem respiration dominates the signal in spite of the fact that SPO is at great distance from the biospheric influence. Due to atmospheric transport, the $\delta^{18} \mathrm{O}$ seasonal cycle of atmospheric $\mathrm{CO}_{2}$ resulting from all biotic exchanges between $30^{\circ} \mathrm{N}$ and $90^{\circ} \mathrm{N}$ presents a phase lag of roughly six months at mid and high latitudes of the southern hemisphere compared to the local $\delta^{18} \mathrm{O}$ seasonal cycle of the $\mathrm{CO}_{2}$ fluxes (see next section for separation of the biosphere into different regions). Thus the signal from the northern biosphere is in phase with the signal from the tropical and southern biosphere (i.e., between $40^{\circ} \mathrm{S}$ and $30^{\circ} \mathrm{N}$ ), as already noticed by Ramonet (1994) for $\mathrm{CO}_{2}$ concentration.

\subsection{Relative contribution of 16 land regions to the $\delta^{18} O$ seasonal cycle}

In this section, we examine the separate contributions of major land eco-regions (photosynthesis plus respiration) to the seasonal cycle and latitudinal gradient of $\delta^{18} \mathrm{O}$ in atmospheric $\mathrm{CO}_{2}$. We choose to divide the globe into several regions in order to examine the contributions of each separately (Fig. 5). The GPP and isotopic parameters are not assumed to be uniform within each region, but rather vary accordingly to the "pattern" defined by the SiB2 model and subsequent Ciais et al. (1997a) calculations (see their Figs. 1b, 2c). 


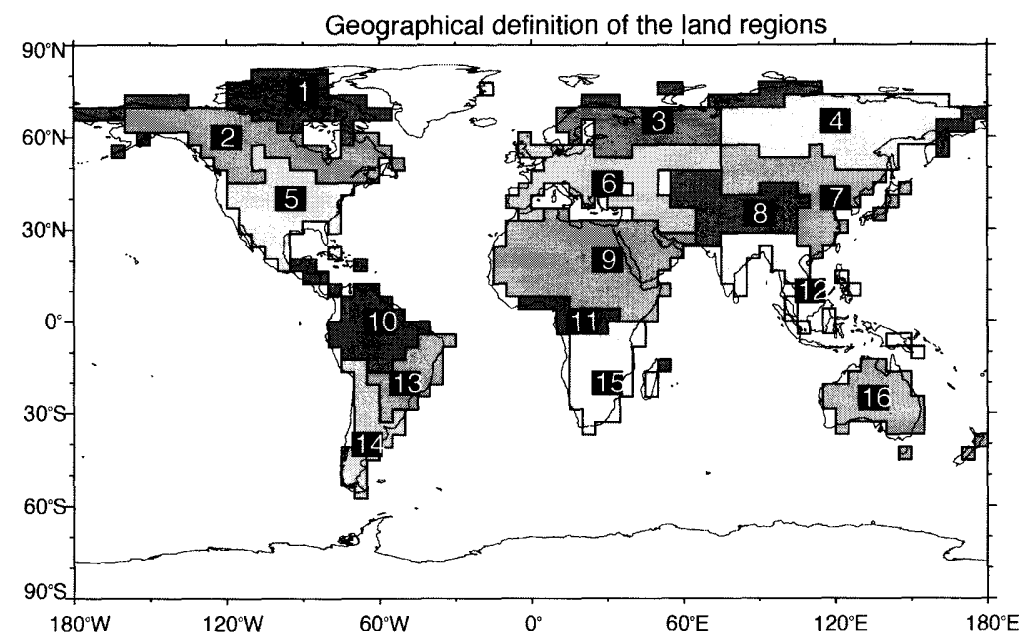

Fig. 5. Geographical boundary for 16 land regions as defined in this study. 1: Tundra; 2,3,4: Taiga (mainly Needleleaf forests) of Canada, northern Europe and northern Siberia; 5,6,7,14: Deciduous forests of Northern America, Europe, Asia and South America; 8,9,13,15,16: savanna (grassland plus shrub cover and desert) of central Asia, northern Africa, South America, southern Africa and Australia; 10,11,12: tropical forests of Amazon, Africa and southern Asia. Note that the denomination "deciduous forests" includes in reality a significant fraction of grass and crop-land especially over North America and Europe.

Our choice of 16 different regions is arbitrary. Yet it is motivated by the need to study different large scale plant functional types, over different geographical areas. The underlying biome classification in SiB2 is the one of Sellers et al. (1996a) (see their Fig. 5). Our region 1 is mostly covered by arctic tundra. Regions 2, 3, and 4 contain boreal forests (mostly Needleleaf trees) of similar type but arbitrarily split into three main areas (Canada, Northern Europe and Northern Siberia) to study the contribution of each. Regions 5, 6, 7, and 14 contain temperate deciduous and occasionally semi-arid ecosystems types. Regions 8, 9, 13, 15, and 16 contain savanna (Grassland plus Shrub) and desert. Finally, regions 10,11 , and 12 are mostly highly productive evergreen and seasonal tropical forests over distinct continents. The transport model was run separately using the emissions of each region and a zero flux everywhere else in order to compute the contribution of a given region to the overall atmospheric $\delta^{18} \mathrm{O}$ signal $(\delta$-anomalies as defined in Section 2$)$. Formally, the simulated $\delta^{18} \mathrm{O}$ seasonal cycle (monthly mean values) can be represented by a vector of 12 dimensions $\left(R^{12}\right)$. One way to define a simple measure for the mean contribution over one year of a given region $\left(V_{\mathrm{i}}\right)$ to the overall seasonal cycle
$\left(V_{\text {tot }}\right)$ is to use a normalized projection of $V_{\mathrm{i}}$ in the direction of $V_{\text {tot }}$ defined as $\left(V_{\mathrm{i}} \cdot V_{\text {tot }}\right) /\left(V_{\text {tot }} \cdot V_{\text {tot }}\right)$ (Kaminski et al., 1996). A large positive value of that quantity indicates that process number $i$ strongly contributes to the total seasonal cycle, whereas a negative value corresponds to a process which generates an individual seasonal variation opposite in phase with the overall seasonal cycle. The sum of all contributions equals $100 \%$.

- High northern latitudes. Fig. 6 presents the simulated seasonal cycle for $\mathrm{CO}_{2}$ and for $\delta^{18} \mathrm{O}$ at $\mathrm{BRW}$ corresponding to given individual regions and their summation (their mean contributions to the overall seasonal cycle are reported in Table 2). Only a few land eco-regions contribute significantly to the seasonal cycle of $\delta^{18} \mathrm{O}$ and $\mathrm{CO}_{2}$ at BRW. Furthermore, a given region does not necessarily affect $\delta^{18} \mathrm{O}$ in a manner similar to $\mathrm{CO}_{2}$. For instance, tundras (region 1, Fig. 5) contribute the same seasonality to $\mathrm{CO}_{2}$ and to $\delta^{18} \mathrm{O}(12 \%$ and $13 \%$, respectively). However there is a large difference in the relative behaviour of the Canadian taiga versus the Northern Siberian taiga (regions 2 and 4, respectively). For $\mathrm{CO}_{2}$, region 2 contributes $30 \%$ to the overall annual cycle as compared to $25 \%$ for region 4 . Moreover, the seasonal cycles of each individual region are 

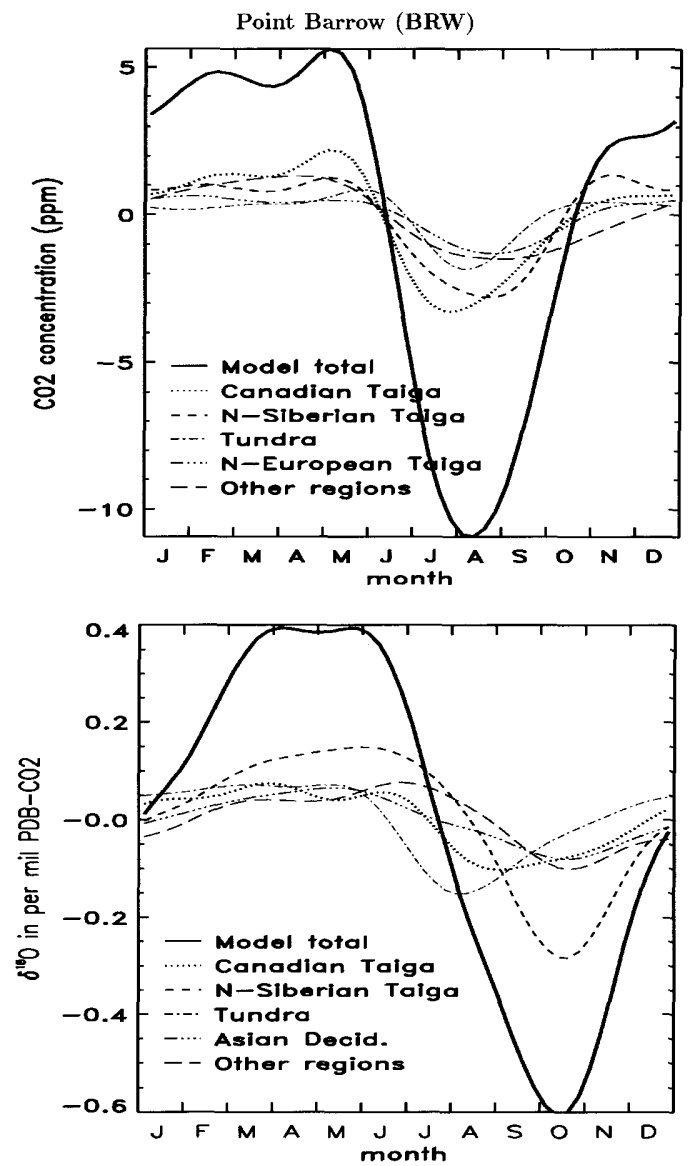

Fig. 6. Simulated mean seasonal cycle (detrended model output) at Point Barrow (BRW) for atmospheric $\mathrm{CO}_{2}$ (upper graph) and for $\delta^{18} \mathrm{O}$ in atmospheric $\mathrm{CO}_{2}$ (lower graph). Solid thick line correspond to the overall model simulation including all processes (terrestrial biosphere, ocean, fossil fuels and deforestation). Thin curves separate the contribution of specific land regions (Fig. 5) to the overall seasonal cycle. Regions with low contribution are brought together into one component "other regions" (see Table 2 for the value of each contribution).

approximately in phase, which produces a sharp drop in the overall concentration between May and August. For $\delta^{18} \mathrm{O}$, Canadian taiga has a weaker influence $(25 \%)$ than northern Siberian taiga $(38 \%)$. The influence of Tundra regions precedes that of all other ecosystems, inducing a first $\delta^{18} \mathrm{O}$ drop in June and July while the October minimum mainly reflects the influence of the North Siberian taiga. Ocean processes, and the release of $\mathrm{CO}_{2}$ from fossil fuel burning and deforestation, induce a very small seasonal cycle at BRW (contributions of $\sim 5 \%$ ) both for $\mathrm{CO}_{2}$ concentration and for $\delta^{18} \mathrm{O}$ in $\mathrm{CO}_{2}$. Other high northern latitudes stations (i.e. ALT, MBC, STM, ICE, and CBA) present the similar behavior, with $\delta^{18} \mathrm{O}$ seasonality dominated by the Northern Siberian taiga (Table 2). The contribution of this particular region is much larger than the contribution of the other regions and explains nearly half of the overall simulated $\delta^{18} \mathrm{O}$ seasonal cycle. On the other hand, the $\mathrm{CO}_{2}$ seasonal cycle is contributed equally by the Canadian taiga and the Northern Siberian taiga.

- Middle northern latitudes. In contrast to the previous set of stations, the $\delta^{18} \mathrm{O}$ seasonal cycle at sites between $35^{\circ} \mathrm{N}$ and $55^{\circ} \mathrm{N}$ is not strongly influenced by the Northern Siberian taiga (region 4, Fig. 5), excepted at SHM and CMO (Table 2). Most of these sites can be considered as "regional" continental stations. Therefore, $\mathrm{CO}_{2}$ exchange by the surrounding land biota exerts a more direct influence on the annual $\delta^{18} \mathrm{O}$ variations at these stations. For instance, at BAL, HUN, and BRN, the deciduous forests of Europe (region 6) largely dominate the seasonal signal both for $\mathrm{CO}_{2}$ and for $\delta^{18} \mathrm{O}$. At UUM and TAP, the $\delta^{18} \mathrm{O}$ as well as the $\mathrm{CO}_{2}$ annual cycles are directly influenced by the deciduous forests of northern Asia (region 7) and the Siberian taiga (region 4). In the case of UUM, we noticed previously a large mismatch of the $\delta^{18} \mathrm{O}$ modeled phase compared to the observations (Fig. 3) which is not present in the $\mathrm{CO}_{2}$ concentration (Fig. 1). The phase discrepancy of $\delta^{18} \mathrm{O}$ indicates that while the net $\mathrm{CO}_{2}$ fluxes prescribed from the $\mathrm{SiB} 2$ model calculations are realistic for those ecosystems (regions 4 and 7), either the $\mathrm{CO}_{2}$ gross fluxes from photosynthesis and respiration are not correctly modeled or the $\delta^{18} \mathrm{O}$ seasonal cycle of the water that isotopically equilibrates with $\mathrm{CO}_{2}$, is out of phase. At NWR, we also find that regions 4 and 7 contribute strongly to the $\delta^{18} \mathrm{O}$ whereas for $\mathrm{CO}_{2}$, the deciduous forests of North America (region 5) are predominant.

- Low latitudes. The $\delta^{18} \mathrm{O}$ seasonal cycle at MLO, KUM, LJO and IZO is again mainly contributed by the Northern Siberian taiga (Table 2). Moreover, as for UUM and TAP the contribution of the deciduous forests of Northern Asia (region 7) is also important. Such character- 
Table 2. Mean seasonal contribution of given terrestrial eco-regions to the overall simulated seasonal cycle (with all components), at specific locations of the northern hemisphere (see Table 1) for $\delta^{18} \mathrm{O}$ of atmospheric $\mathrm{CO}_{2}$ and for $\mathrm{CO}_{2}$ concentration, respectively $\left(\delta^{18} \mathrm{O}\right.$ number $/ \mathrm{CO}_{2}$ number $)$

\begin{tabular}{|c|c|c|c|c|c|c|c|c|c|}
\hline (GPP) & $\begin{array}{l}\text { N-Amer. } \\
\text { tun. } \\
\text { (1) }\end{array}$ & $\begin{array}{c}\text { Canad. } \\
\text { taiga } \\
(5)\end{array}$ & $\begin{array}{c}\text { Euro. } \\
\text { taiga } \\
(3)\end{array}$ & $\begin{array}{c}\text { Siber. } \\
\text { taiga } \\
(5)\end{array}$ & $\begin{array}{c}\text { N-Amer. } \\
\text { deci. } \\
(6)\end{array}$ & $\begin{array}{l}\text { Euro. } \\
\text { deci. } \\
(5)\end{array}$ & $\begin{array}{l}\text { Asia } \\
\text { deci. } \\
(5)\end{array}$ & $\begin{array}{c}\text { Other } \\
\text { ecosys. } \\
(71)\end{array}$ & $\begin{array}{c}\text { Oce-Fos } \\
\text { def }\end{array}$ \\
\hline \multicolumn{10}{|c|}{ High-latitude sites } \\
\hline ALT & $9 / 8$ & $20 / 26$ & $9 / 14$ & $39 / 24$ & $5 / 4$ & $-1 / 14$ & $14 / 7$ & $2 /-4$ & $3 / 8$ \\
\hline $\mathrm{MBC}$ & $9 / 9$ & $18 / 26$ & $10 / 14$ & $40 / 25$ & $4 / 4$ & $-1 / 13$ & $14 / 6$ & $2 /-4$ & $4 / 7$ \\
\hline BRW & $13 / 12$ & $17 / 29$ & $7 / 11$ & $39 / 25$ & $4 / 3$ & $-1 / 11$ & $14 / 6$ & $4 /-3$ & $5 / 6$ \\
\hline STM & $9 / 6$ & $18 / 32$ & $11 / 15$ & $30 / 20$ & $6 / 5$ & $2 / 17$ & $14 / 7$ & $3 /-5$ & $7 / 5$ \\
\hline ICE & $11 / 6$ & $23 / 33$ & $6 / 12$ & $31 / 21$ & $5 / 5$ & $0 / 13$ & $15 / 7$ & $4 /-4$ & $5 / 7$ \\
\hline MHT & $9 / 6$ & $19 / 36$ & $5 / 11$ & $29 / 21$ & $6 / 5$ & $5 / 13$ & $15 / 8$ & $4 /-5$ & $6 / 5$ \\
\hline CBA & $27 / 20$ & $7 / 13$ & $8 / 10$ & $50 / 39$ & $2 / 3$ & $5 / 10$ & $3 / 9$ & $-2 /-3$ & $0 / 0$ \\
\hline SHM & $15 / 13$ & $9 / 17$ & $6 / 12$ & $46 / 35$ & $3 / 4$ & $0 / 12$ & $14 / 10$ & $3 /-4$ & $5 / 2$ \\
\hline \multicolumn{10}{|c|}{ Mid-latitude sites } \\
\hline BAL & $7 / 2$ & $13 / 18$ & $10 / 18$ & $20 / 8$ & $4 / 4$ & $21 / 59$ & $11 / 3$ & $1 /-4$ & $15 /-9$ \\
\hline HUN & $5 / 0$ & $10 / 13$ & $4 / 6$ & $16 / 4$ & $4 / 5$ & $43 / 81$ & $9 / 2$ & $-1 /-5$ & $8 /-7$ \\
\hline BRN & $6 / 1$ & $12 / 16$ & $4 / 4$ & $19 / 6$ & $4 / 4$ & $36 / 73$ & $10 / 2$ & $-2 /-5$ & $11 /-2$ \\
\hline $\mathrm{CMO}$ & $10 / 7$ & $11 / \mathbf{3 1}$ & $6 / 11$ & $39 / 25$ & $4 / 5$ & $0 / 13$ & $19 / 10$ & $3 /-4$ & $6 / 3$ \\
\hline NWR & $10 /-1$ & $11 / 15$ & $7 / 3$ & $43 / 6$ & $7 / 66$ & $0 / 7$ & $30 / 6$ & $-13 /-9$ & $5 / 5$ \\
\hline UUM & $3 / 2$ & $3 / 13$ & $5 / 13$ & $22 / 25$ & $2 / 4$ & $1 / 14$ & $55 / 29$ & $5 /-2$ & $5 / 2$ \\
\hline TAP & $5 / 1$ & $8 / 10$ & $7 / 9$ & $34 / 16$ & $4 / 4$ & $1 / 12$ & $32 / 26$ & $-4 /-3$ & $12 / 25$ \\
\hline QPC & $3 / 0$ & $5 / 9$ & $3 / 8$ & $8 / 6$ & $5 / 4$ & $2 / 10$ & $16 / 11$ & $56 / 55$ & $3 /-2$ \\
\hline \multicolumn{10}{|c|}{ Low-latitude sites } \\
\hline LJO & $9 / 4$ & $11 / 24$ & $8 / 12$ & $37 / 22$ & $10 / 3$ & $1 / 15$ & $21 / 11$ & $-11 /-2$ & $14 / 10$ \\
\hline IZO & $9 / 5$ & $16 / 27$ & $5 / 13$ & $34 / 23$ & $12 / 1$ & $0 / 12$ & $23 / 11$ & $-4 / 4$ & $5 / 4$ \\
\hline KUM & $11 / 5$ & $12 / \mathbf{2 0}$ & $8 / 12$ & $47 / 22$ & $7 / 6$ & $1 / 15$ & $27 / 11$ & $-17 / 3$ & $3 / 7$ \\
\hline MLO & $12 / 4$ & $15 / 20$ & $10 / 11$ & $\mathbf{5 2} / 18$ & $5 / 6$ & $6 / 12$ & $32 / 9$ & $-37 / 11$ & $5 / 10$ \\
\hline
\end{tabular}

See text for definition of the mean contribution (the sum of all contributions at each station is $100 \%$ ). The geographical partitioning of the different regions corresponds to Fig. 5. "tun.", tundra; "taiga", mainly needleleaf forest; "deci.", deciduous forest. We brought together regions with low contribution. In bold are the contributions larger than 20\%. GPP (numbers in parentheses) represent the Gross Primary Production (i.e. total $\mathrm{CO}_{2}$ assimilation in $\mathrm{GtC}$ year $^{-1}$ ).

istics at IZO which is at high altitude and far away from the Asian continent, indicate that the whole northern hemisphere $\delta^{18} \mathrm{O}$ seasonal cycle is dominated by the Northeast Asian biosphere (regions 4 and 7). For $\mathrm{CO}_{2}$, the seasonal contribution of the Canadian taiga is proportionally larger than for $\delta^{18} \mathrm{O}$.

- Southern hemisphere. CGO and SPO show, on the other hand, major contributions to the $\delta^{18} \mathrm{O}$ seasonal cycle from all southern hemisphere ecosystems (Table 3). More precisely, the tropical forests of South America (region 10), which exchange a large quantity of $\mathrm{CO}_{2}\left(15 \mathrm{GtC}\right.$ year $\left.^{-1}\right)$ and the savannas of South America and Southern Africa (regions 13 and 15) dominate the $\delta^{18} \mathrm{O}$ annual cycle. Ecosystems of the northern hemi- sphere, above $30^{\circ} \mathrm{N}$ (grouped in the "Other Ecosystems" component) explain only $\sim 15 \%$ of the seasonal variations. Whereas for the $\mathrm{CO}_{2}$ concentration, the ocean exchange contributes to $\sim 60 \%$ of the annual cycle at CGO and SPO, for $\delta^{18} \mathrm{O}$ the ocean represents less than $15 \%$.

From the above analysis we can draw the following conclusions. (1) The air-sea exchange, the burning of fossil fuels and the deforestation do not contribute significantly to the mean $\delta^{18} \mathrm{O}$ seasonal cycle compared to the land biotic fluxes. (2) According to our model, the Northern Siberian taiga (region 4) dominates the $\delta^{18} \mathrm{O}$ seasonality at all remote stations of the northern hemisphere, although it is not as dominant in influencing the $\mathrm{CO}_{2}$ seasonal cycle. There is no obvious correla- 
Table 3. As Table 2 but the southern hemisphere

\begin{tabular}{lcccccccccc}
\hline & $\begin{array}{c}\text { N-Amer. } \\
\text { tro. } \\
\text { (GPP) }\end{array}$ & $\begin{array}{c}\text { Afri. } \\
\text { tro. } \\
(15)\end{array}$ & $\begin{array}{c}\text { S-Amer. } \\
\text { sava. } \\
(5)\end{array}$ & $\begin{array}{c}\text { N-Afri. } \\
\text { sava. } \\
(10)\end{array}$ & $\begin{array}{c}\text { S-Afri. } \\
\text { sava. } \\
(11)\end{array}$ & $\begin{array}{c}\text { Austr. } \\
\text { sava. } \\
(14)\end{array}$ & $\begin{array}{c}\text { S-Amer. } \\
\text { deci. } \\
(2)\end{array}$ & $\begin{array}{c}\text { Other } \\
\text { ecosys. } \\
(39)\end{array}$ & Oceean & Fos-Def \\
\hline CGO & $\mathbf{2 5} / 8$ & $4 / 2$ & $\mathbf{2 2} /-5$ & $1 / 8$ & $19 /-1$ & $5 /-3$ & $0 / 7$ & $11 / 10$ & $16 / 77$ & $-3 /-3$ \\
SPO & $\mathbf{2 4} / 9$ & $4 / 2$ & $17 /-5$ & $2 / 10$ & $18 /-1$ & $9 /-5$ & $3 / 11$ & $16 / 12$ & $10 / 65$ & $-2 / 2$ \\
\hline
\end{tabular}

"tro.", tropical forest; "sava.", savana (i.e, grassland plus shrub).

tion between the strength of the $\mathrm{CO}_{2}$ gross fluxes of each ecosystem (GPP given in Tables 2,3) and its mean contribution to the $\delta^{18} \mathrm{O}$ seasonal cycle. The dominant ecosystem for $\delta^{18} \mathrm{O}$, i.e. region 4 , assimilates $\sim 4.8 \mathrm{TC} \mathrm{ha}^{-1}$ year $^{-1}\left(5 \mathrm{GtC}\right.$ year $^{-1}$ in total) which is smaller to region 5 (the deciduous forests of North America) with 6.2 $\mathrm{TC} \mathrm{ha}^{-1}$ year $^{-1}$ (6 GtC year ${ }^{-1}$ in total).

As previously noted, the amplitude of the simulated $\delta^{18} \mathrm{O}$ seasonal cycle depends on several factors including the isotopic fractionation, $\alpha_{s}$ and $\alpha_{1}$. Nevertheless changing globally from one set of values for $\alpha_{1}$ and $\alpha_{s}$ to another would not significantly change the relative contribution of each region to the overall signal, since the amplitude of the seasonal cycle is scaled in the same proportion for each biome. The sensitivity of these results to the hydrological cycle (i.e., $\delta^{18} \mathrm{O}$ of the precipitation) is tackled in Subsection 4.2.

\subsection{Relative contribution of 16 land regions to the mean $\delta^{18} O$ latitudinal gradient}

Fig. 7 compares the zonally averaged simulated $\delta^{18} \mathrm{O}$ field with the NOAA-CU, the Scripps-CIO, and the CSIRO observations. The overall simulated latitudinal profile presents a decrease of $-1.5 \%$ from south to north which compares reasonably well with the data, except in the tropics. This northward model decrease includes a drop of $\sim 1 \%$ between $40^{\circ} \mathrm{S}$ and the equator and a smaller drop of $\sim 0.5 \%$ o between the equator and $60^{\circ} \mathrm{N}$. The atmospheric measurements indicate a large decrease between $30^{\circ} \mathrm{N}$ and $60^{\circ} \mathrm{N}$ and the tropical $\delta^{18} \mathrm{O}$ observations from the Scripps-CIO network are much higher than the modeled values, as already pointed out by Ciais et al. (1997b). For instance, at Fanning Island (LIN in Fig. 7), KUM, and MLO the difference between model and data is of the order of $0.5 \%$. Note that because tropical sites are measured without drying the air, the $\delta^{18} \mathrm{O}$ observations might be too low on average (see discussion Subsection 3.1) which will also enhance the discrepancy between model and data over the tropics. The underestimation of $\delta^{18} \mathrm{O}$ in the tropics by the model results directly from the presence of depleted $\mathrm{CO}_{2}$ over South America and Equatorial Africa (graph not shown). More specifically, regions 9 to 16 (Fig. 5) are responsible for this effect, which directly reflects the low isotopic signature of respired $\mathrm{CO}_{2}$, whereas leaf retrodiffused $\mathrm{CO}_{2}$ would tend to enhance $\delta^{18} \mathrm{O}$ in the tropics (Fig. 7). Concerning $\delta^{18} \mathrm{O}$ at mid and high latitudes, we find, just as for the mean seasonal cycle, that the respiration of the biosphere above $30^{\circ} \mathrm{N}$ (i.e., regions 1 to 9, Fig. 5) controls the mean simulated latitudinal gradient. Photosynthesis of regions 1 to 9 increases the $\delta^{18} \mathrm{O}$ between $10^{\circ} \mathrm{N}$ and $60^{\circ} \mathrm{N}$ by $\sim 0.3 \%$ while photosynthesis of regions located south of $30^{\circ} \mathrm{N}$ decreases it by nearly the same amount. Fossil fuel burning and air-sea exchange only produce a substantial variation of the zonal mean $\delta^{18} \mathrm{O}$ between $40^{\circ} \mathrm{S}$ and $10^{\circ} \mathrm{N}(\sim 0.5 \%)$.

In order to investigate the reasons for the low $\delta^{18} \mathrm{O}$ simulated values over the tropics, we performed two tests in which the $\delta^{18} \mathrm{O}$ value of the water pools that isotopically exchange with $\mathrm{CO}_{2}$ during photosynthesis and respiration is enhanced. First, the GISS model probably underestimates the $\delta^{18} \mathrm{O}$ of meteoric water by nearly $2 \%$ over tropical continents, as discussed by Jouzel et al. (1987). We added a constant offset of $+2 \%$ to the GISS monthly mean values of $\delta^{18} \mathrm{O}$ in precipitation between $20^{\circ} \mathrm{S}$ and $20^{\circ} \mathrm{N}$. The result of this sensitivity experiment is to enhance the $\delta^{18} \mathrm{O}$ in $\mathrm{CO}_{2}$ around the equator by $0.15 \%$ which still under-predicts the observations. Secondly, the isotopic enrichment of chloroplast water during photosynthesis depends among other variables on the $\delta^{18} \mathrm{O}$ of the water vapor inside the canopy 


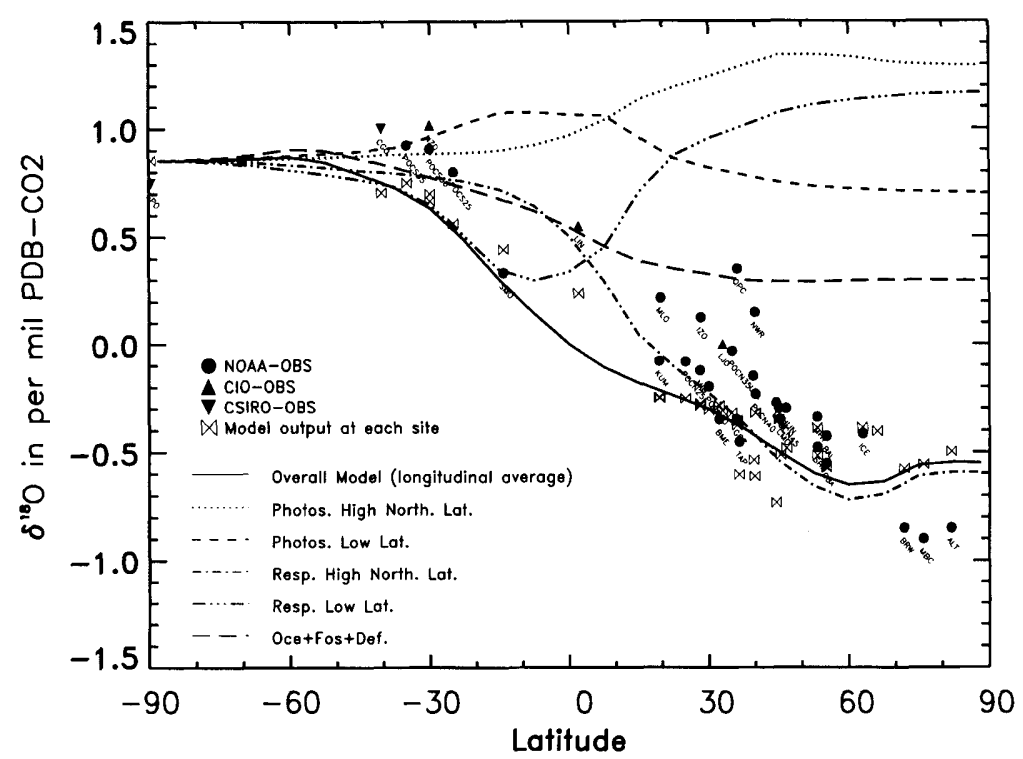

Fig. 7. Zonally averaged latitudinal profile of $\delta^{18} \mathrm{O}$ in $\mathrm{CO}_{2}$ at the earth surface. Modeled $\delta^{18} \mathrm{O}$ decomposes into several components that separate the exchange of $\mathrm{CO}_{2}$ during photosynthesis and respiration for both the high northern latitudes and low latitudes ecosystems (regions 1 to 8 , and 9 to 16, respectively, as defined in Fig. 5), and the exchange of $\mathrm{CO}_{2}$ associated to the processes. Each profile is referenced relative to the value of $+0.85 \%$ at the South Pole (the observed average $\delta^{18} \mathrm{O}$ measured by CSIRO in 1990) and combine linearly to yield the overall modeled $\delta^{18} \mathrm{O}$ (solid line). Solid symbols correspond to $\delta^{18} \mathrm{O}$ values simulated at the precise location of the air sampling sites and are the average of atmospheric data measured on flasks samples by NOAA-CU (circles), ScrippsCIO (triangles up) and by CSIRO (triangles down). Several sites not used in the discussion of the $\delta^{18} \mathrm{O}$ seasonality (Table 1) have been added to better define the observed mean latitudinal gradient.

(eq. (A2)). This quantity is approximated in our model by the $\delta^{18} \mathrm{O}$ of the water vapor at the first level of the GISS model, which might underestimate the value inside the canopy. $\delta^{18} \mathrm{O}$ of water vapor inside "closed" canopy system, like tropical forest, is indeed a mixture between free tropospheric water vapor and plant transpired water vapor. This latter water vapor reflects the isotopic content of the precipitation which is enriched in ${ }^{18} \mathrm{O}$ compared to the tropospheric water vapor (White and Gedzelman, 1984; Jacob and Sonntag, 1991). We thus increased the $\delta^{18} \mathrm{O}$ of the water vapor between $20^{\circ} \mathrm{S}$ and $20^{\circ} \mathrm{N}$ to an unlikely upper bound corresponding to the $\delta^{18} \mathrm{O}$ of precipitation (i.e., assuming that vapor in the canopy consists entirely of plant transpiration). In this case, the too low model $\delta^{18} \mathrm{O}$ estimates around the equator are augmented by $0.35 \%$. At LIN the model value becomes only $0.25 \%$ o lower than the observations instead of $0.5 \%$ initially. From these two tests, we can see that first the $\delta^{18} \mathrm{O}$ of the water vapor inside the canopy is a crucial parameter and secondly that combining the two effects would produce modeled $\delta^{18} \mathrm{O}$ values in better agreement with the Scripps-CIO observations in the tropics. Nevertheless, the model would still underestimate the $\delta^{18} \mathrm{O}$ in the northern tropics (MLO, KUM, and LJO) by roughly $0.4 \%$.

\section{Different behavior of $\mathbf{1 6}$ land regions with respect to $\delta^{18} \mathrm{O}$ fluxes}

In Section 3, we have shown evidence of large differences among terrestrial ecosystems regarding their contribution to the $\delta^{18} \mathrm{O}$ seasonal cycle at specific locations around the world as well as to the latitudinal gradient. As a next step, we would like to determine whether such differences arise from distinct $\mathrm{CO}_{2}$ gross fluxes (photosynthesis and respiration) or from distinct climate variables (i.e., the isotopic composition of the precipitation, 
the temperature, the relative humidity and the evaporation of soil water which influence the isotopic equilibrium between $\mathrm{CO}_{2}$ and $\mathrm{H}_{2} \mathrm{O}$ ).

\subsection{Global differences between the 16 regions}

The product of the gross $\mathrm{CO}_{2}$ flux and the discrimination is the quantity which determines the variations of $\delta^{18} \mathrm{O}$ in atmospheric $\mathrm{CO}_{2}$ induced by each region and by each process. Fig. 8 shows the seasonal influence of this isotopic exchange for the 16 eco-regions. Tropical regions (upper graph) do not exhibit strong seasonality with maximum changes between two consecutive months lower than $6 \mathrm{GtC} \%$ except for the South American tropical forests and Southern African savanna (regions 10 and 15 , with 22 and $19 \mathrm{GtC} \%$ month ${ }^{-1}$, respectively). This weak seasonality in the $\mathrm{CO}_{2}$ isotope flux is further damped and smoothed out by the atmospheric transport. Hence, the $\delta^{18} \mathrm{O}$ seasonal contribution of these tropical ecosystems to the northern hemisphere stations is small (see Tables 2, 3, Subsection 3.3). Amazonia and Southern Africa (regions 10 and 15 ) on the other hand, lead locally to a huge seasonal imprint on the atmosphere. Such large seasonal cycles are also not clearly seen at the existing tropical sites or at northern sites, because of the following reason. Vertical transport (large scale transport and convection) is intense enough over the tropics to strongly dilute the $\delta^{18} \mathrm{O}$ seasonal changes higher up in the troposphere. Hence, surface oceanic stations in the tropics and subtropics detect only small variations. Above Ascension Island in the Atlantic ocean near the equator, the major contributors to the $\delta^{18} \mathrm{O}$ seasonal cycle between 3000 and $12000 \mathrm{~m}$ ( $\sigma$ level 4 and 7 ), are indeed regions 10 and 15 .

The $\delta^{18} \mathrm{O}$ seasonal oscillation associated with northern temperate and boreal regions goes through a minimum in June, July and August (JJA) (lower graph, Fig. 8). The isotopic exchange with the Northern Siberian taiga (region 4) has a huge seasonal amplitude of $\sim 20 \mathrm{GtC} \%$ month ${ }^{-1}$ with a marked minimum in August. For other mid and high latitudes regions, the amplitude of the isotopic flux is on the order of $10 \mathrm{GtC} \%$ month $^{-1}$. As opposed to the tropics, the large scale vertical transport at high latitudes is much weaker throughout the year and convention only significantly affects on average the three lowest levels of the model $(2500 \mathrm{~m})$ compared to the five lowest levels $(7000 \mathrm{~m})$ in the tropics (Ramonet, 1994). Thus the $\delta^{18} \mathrm{O}$ flux emitted by northern Siberia is wide spread in the lower troposphere of the entire northern hemisphere. Note, that the Canadian taiga (region 2) which is similar to region 4 with respect to the annual $\mathrm{CO}_{2}$ gross fluxes, induces on the contrary a smaller isotopic seasonal variation. In the following, we will examine the reasons for this difference.

\subsection{Differences between Canadian and Northern Siberian taigas}

Canadian and Northern Siberian taigas (regions 2 and 4, respectively and referred to later in this paragraph as "Canada" and "Siberia") predominantly contain needleleaf tree species. Fig. 9 separates the contributions of photosynthesis and respiration to the overall isotopic signal (lower graph). The summer decrease in $\delta^{18} \mathrm{O}$ associated with respiration is clearly depicted. However, in spring and early summer, photosynthesis yields at opposing increase in ${ }^{18} \mathrm{O}$. We have to multiply the $\mathrm{CO}_{2}$ flux with the corresponding $\delta^{18} \mathrm{O}$ discrimination (upper graphs). Each region assimilates $5 \mathrm{GtC}$ year $^{-1}$, although the summer maximum of photosynthesis is slightly higher for Siberia (the growing season is shorter in Siberia compared to Canada because of its more interior continental location). However the larger $\mathrm{CO}_{2}$ assimilation rate in July and August for Siberia is combined with much weaker $(\sim 5 \%)$ photosynthetic discrimination $\left(\Delta_{A}\right.$, eq. (A3)) compared to Canada. This latter effect dominates and hence, the overall isotopic seasonal contribution of photosynthesis is much weaker for Siberia than for Canada over the entire growing season. Note that if both leaf discriminations were more positive, the product with $\mathrm{CO}_{2}$ fluxes would give even larger amplitudes for the photosynthetic $\delta^{18} \mathrm{O}$ seasonal cycle and the difference between the two regions would be enhanced.

The seasonality of the soil respired $\mathrm{CO}_{2}$ flux is more pronounced for Siberia than Canada. Very cold soil temperatures which inhibit the respiration flux extend over a longer period (centered in winter) in Siberia. The soil discrimination $\left(\Delta_{R}\right.$, eq. (A3)) is more negative in Siberia by 1 to $3 \%$. In this case, both differences $\left(\mathrm{CO}_{2}\right.$ fluxes and $\left.\Delta_{R}\right)$ combine together in the same way and after taking their product, the seasonal amplitude of the 


\section{Biospheric Isotopic Signal before transport}

\section{(seasonal cycle)}
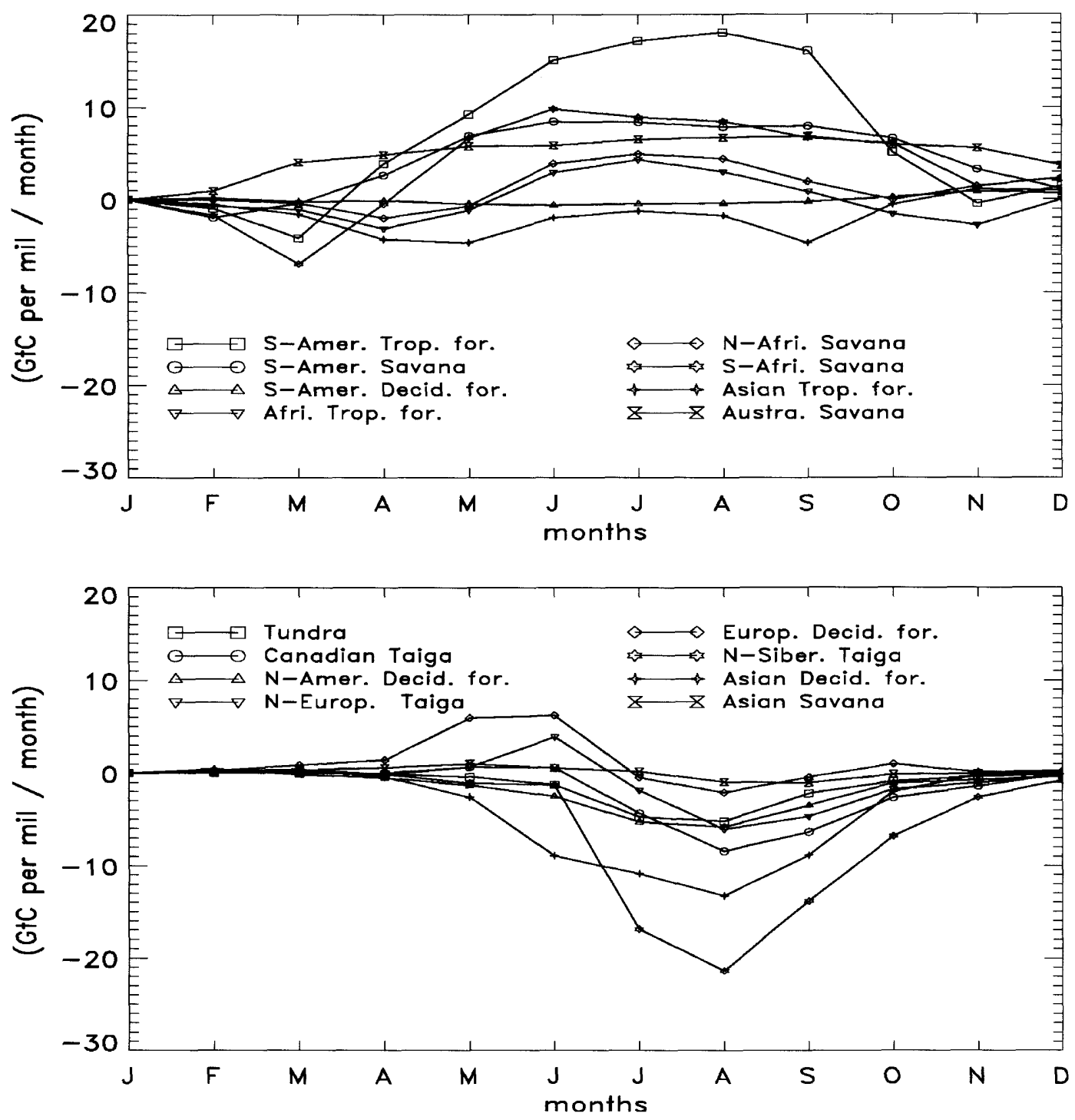

Fig. 8. Seasonal variations of the flux of $\delta^{18} \mathrm{O}$ in atmospheric $\mathrm{CO}_{2}$ (in $\mathrm{GtC} \%$ month ${ }^{-1}$ ) from 16 land ecosystems (Fig. 5), before atmospheric transport. Values represent the overall contribution of photosynthesis and respiration $\left(A \Delta_{\mathrm{A}}+F_{\text {resp }} \Delta_{\mathrm{R}}\right.$, eq. (A3)). All curves are shifted to zero in January as we will only discuss the seasonality of the fluxes.

isotopic contribution of the respiration is larger for Siberia than for Canada.

The overall biospheric effect (photosynthesis plus respiration) produces a large $\delta^{18} \mathrm{O}$ depletion in July, August, and September for $\mathrm{CO}_{2}$ emitted by Siberia and a smaller one for Canada. In the case of Siberia, the total biospheric signal is mostly due to respiration while for Canada, photosyn- 

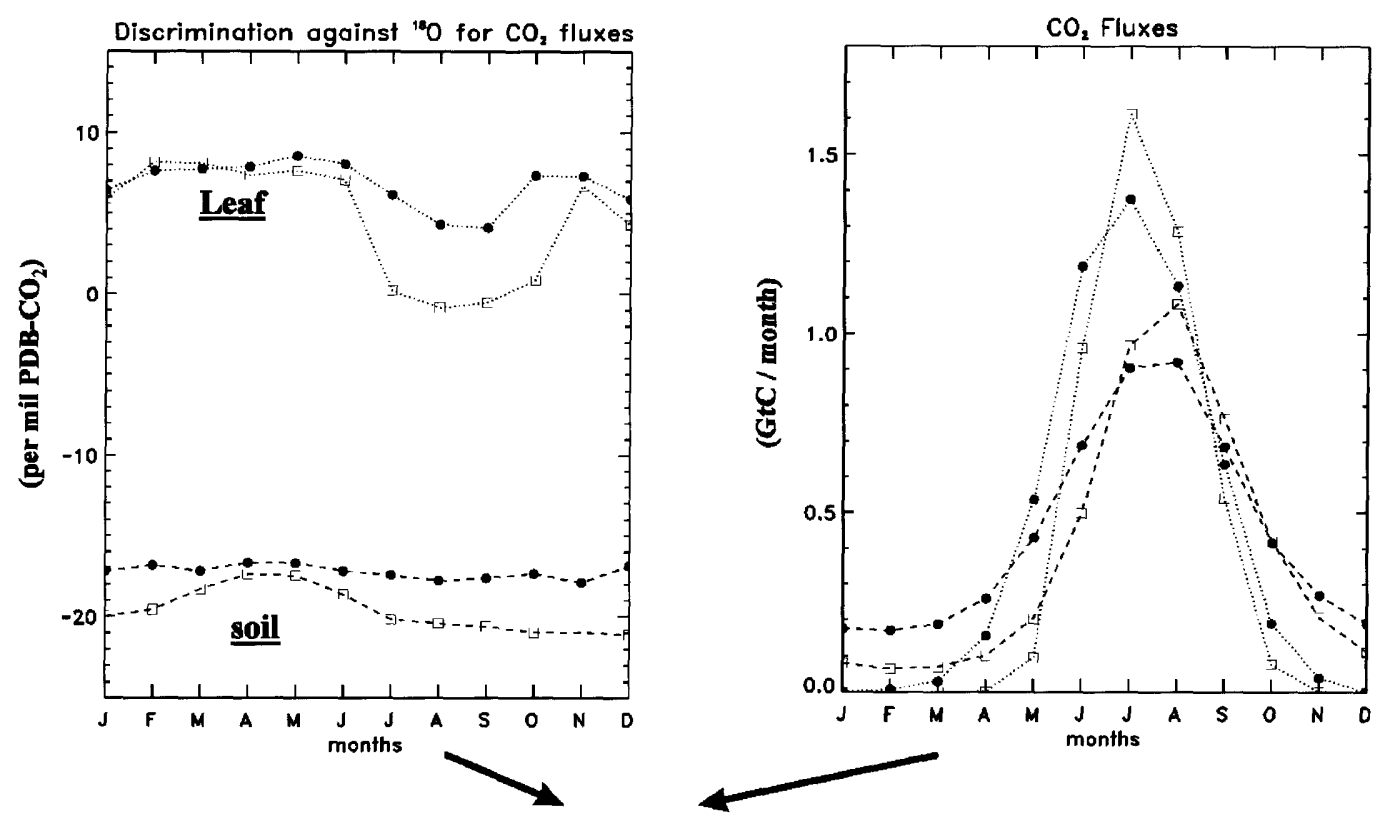

\section{PRODUCT}

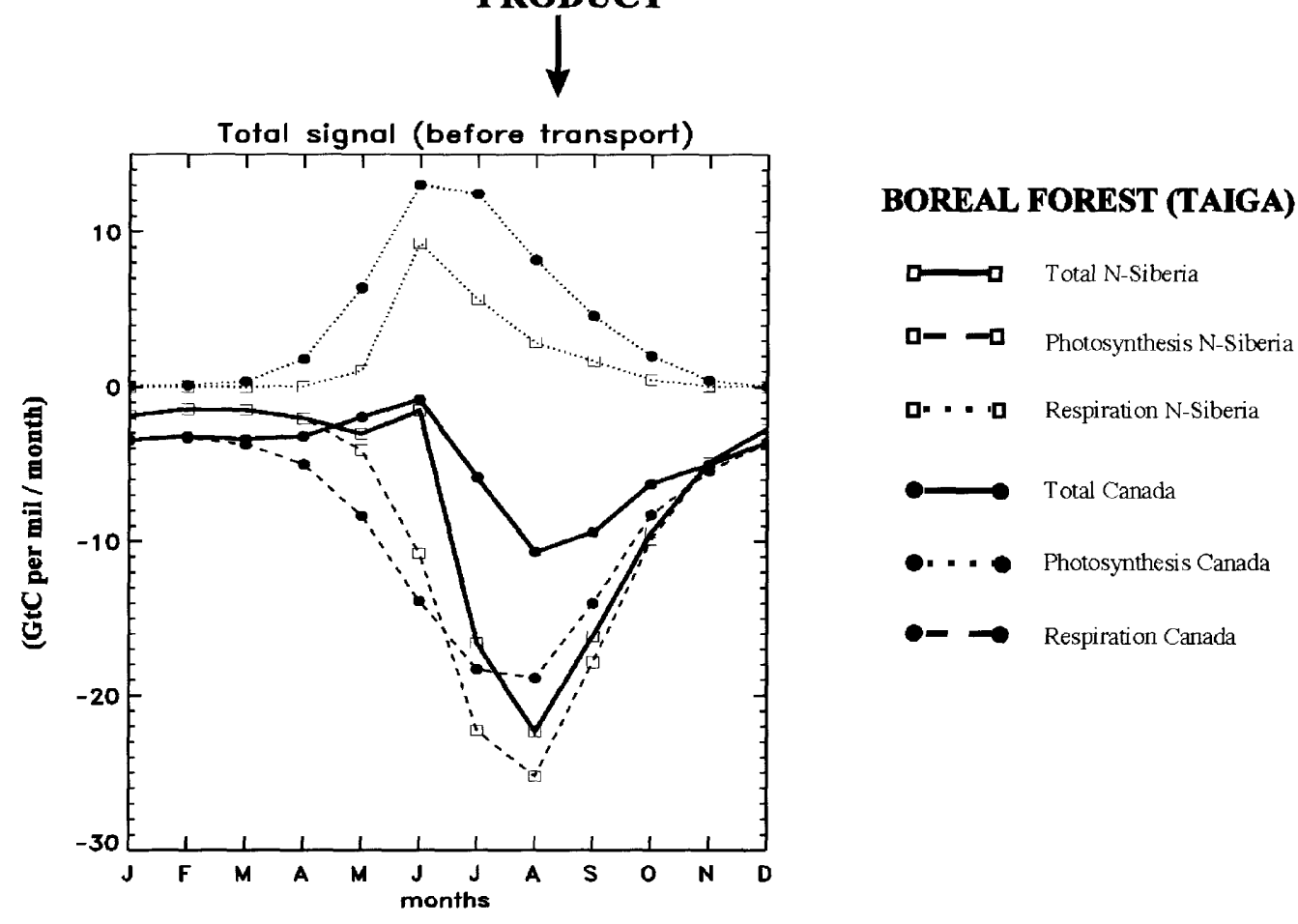

Fig. 9. Seasonal variations of the flux of $\delta^{18} \mathrm{O}$ in atmospheric $\mathrm{CO}_{2}$ (in $\mathrm{GtC} \%$ month ${ }^{-1}$, lower graph) from the northern Siberian taiga and the Canadian taiga (regions 4 and 2, respectively, Fig. 5), before atmospheric transport. The overall contribution (solid lines) is the sum of the photosynthesis and respiration contributions $\left(A \Delta_{\mathrm{A}}\right.$ and $F_{\mathrm{resp}} \Delta_{\mathrm{R}}$, respectively, eq. (A3)), for each region. The isotopic signal from photosynthesis and respiration results from a product between the $\mathrm{CO}_{2}$ flux (net assimilation and ecosystem respiration, respectively; upper right graph) and the discrimination against ${ }^{18} \mathrm{O}$ compared to ${ }^{16} \mathrm{O}$ associated with this flux (upper left graph). 
thesis is also important. We find that for respiration, a variation of $1 \mathrm{GtC}$ month ${ }^{-1}$ of the $\mathrm{CO}_{2}$ flux in summer is equivalent in terms of its influence on the $\delta^{18} \mathrm{O}$ of atmospheric $\mathrm{CO}_{2}$ to a variation of $\sim 18 \%$ of the discrimination and for photosynthesis the equivalence in only $1 \mathrm{GtC}$ month ${ }^{-1}$ for $\sim 3.3 \%$ o (these ratios correspond to July). With such ratios, inter-annual variations of $\delta^{18} \mathrm{O}$ in atmospheric $\mathrm{CO}_{2}$ should be more sensitive to changes in $\mathrm{CO}_{2}$ fluxes and especially to the release of $\mathrm{CO}_{2}$ by respiration rather than to changes in the isotopic content of the water pools. This is relevant to detection of large-scale changes in ecosystem functioning.

We now compare the annual variation of the discrimination between these eco-regions (Fig. 10). The temperature dependence of the isotopic exchange between $\mathrm{CO}_{2}$ and $\mathrm{H}_{2} \mathrm{O}\left(\varepsilon_{\text {equ }}\right)$ enters in the calculation of the discriminations, $\Delta_{A}$ and $\Delta_{R}$ (see Section 7). During the growing season, differences between Siberia and Canada arise essentially from differences in the $\delta^{18} \mathrm{O}$ of meteoric water, since differences in temperature are on the order of $3^{\circ} \mathrm{C}$ (i.e., $0.6 \%$ change in $\varepsilon_{\text {equ }}$ ). The $\delta^{18} \mathrm{O}$ of soil moisture is modeled to be almost identical to the $\delta^{18} \mathrm{O}$ of meteoric water and thus has a strong seasonality with lowest values in winter. Moreover, because of its more interior continental location, Siberia receives precipitation more depleted in ${ }^{18} \mathrm{O}$ than Canada (IAEA, 1992; Rozanski et al., 1992). Leaf water shows a comparable degree of enrichment with respect to soil moisture in both regions (except in May and June with a larger enrichment for Siberia).

From this analysis, we can draw two main conclusions: Firstly the soil discrimination (the $\delta^{18} \mathrm{O}$ of respired $\mathrm{CO}_{2}$ ) is modeled as constant over the course of a year both over Canadian and Northern Siberian taigas. As a consequence, the isotopic signal due to respiration is directly proportional to the net release of $\mathrm{CO}_{2}$ by soils. Secondly, the much larger seasonal amplitude of the $\delta^{18} \mathrm{O}$ exchange fluxes over Northern Siberia vs. Canada is determined by lower values of the discriminations $\left(\Delta_{A}\right.$ and $\left.\Delta_{R}\right)$ in Northern Siberia, reflecting the lower $\delta^{18} \mathrm{O}$ in meteoric water and a stronger seasonality in the $\mathrm{CO}_{2}$ fluxes.

\subsection{Comparison with the BOREAS field measurements}

It is of particular interest to compare our modeled $\delta^{18} \mathrm{O}$ fluxes to ground based measure- ments. While progress has been made in laboratory experiments to decipher the oxygen isotope exchange during leaf photosynthesis (Yakir et al., 1994; Wang and Yakir, 1995), few studies have addressed the isotope composition of soil emitted $\mathrm{CO}_{2}$ (Hesterberg and Siegenthaler, 1991; Tans, 1998). Furthermore, field measurements of $\delta^{18} \mathrm{O}$ in $\mathrm{CO}_{2}$ within field canopies have been few (Flanagan et al., 1997; Miranda et al., 1994). Recently, Flanagan et al. (1997) have obtained results from a field campaign in the Canadian boreal forest, as part of the BOREAS experiment (Sellers et al., 1995), which are briefly compared in the following to the predictions of our model. A relevant detailed comparison with measurements at specific location is indeed very difficult because of the size of the grid cell in our model: $\sim 500 \mathrm{~km}$ by $500 \mathrm{~km}$. We have here sampled the global model output on the two grid cells corresponding to the two sites studied by Flanagan, respectively the Southern Study Area (SSA, $\left.53.1^{\circ} \mathrm{N}, 105.5^{\circ} \mathrm{W}\right)$ and the Northern Study Area (NSA, $55.5^{\circ} \mathrm{N}, 97.5^{\circ} \mathrm{W}$ ).

- $\delta^{18} O$ of meteoric water and canopy water vapor. The $\delta^{18} \mathrm{O}$ of meteoric water predicted by the GISS model in the low resolution version used by Jouzel et al. (1987) $\left(8^{\circ}\right.$ by $\left.10^{\circ}\right)$ reaches a maximum in summer $(-10 \% 0)$ and a minimum in winter $(-20 \%)$. Although the phase and the amplitude of the modeled $\delta^{18} \mathrm{O}$ agrees roughly with the observations, the GISS model overestimates $\delta^{18} \mathrm{O}$ in precipitation by $\sim 3 \%$ in JJA, and by $\sim 7 \%$ in January, February, and March (JFM) (Fig. 11, upper graph). Similar to the precipitation, the model predicted $\delta^{18} \mathrm{O}$ of water vapor is greater by $\sim 3 \%$ than the BOREAS observations (graph not shown).

- Leaf water $\delta^{18} O$. Flanagan et al. (1997) have shown that the observed leaf water $\delta^{18} \mathrm{O}$ can be well predicted by the Craig and Gordon (1965) equation (eq. (A2)), using the observed values for $h, T_{\text {leaf }}, \delta_{\mathrm{s}}^{\mathrm{w}}, \delta_{\text {vap }}^{\mathrm{w}}$ (input variables). In this study, we use as input variables the GISS model for isotopes and the CSU GCM for climate variables. Despite the fact that modeled $\delta^{18} \mathrm{O}$ in precipitation and canopy vapor are larger than observed, the modeled leaf water $\delta^{18} \mathrm{O}$ is lower on average $(\sim 4 \%)$ than the BOREAS measurements. The main reason is that the relative humidity $(h)$ is larger by $\sim 26 \%$ than the observations which gives more weight to water vapor $\delta^{18} \mathrm{O}$ (usually 

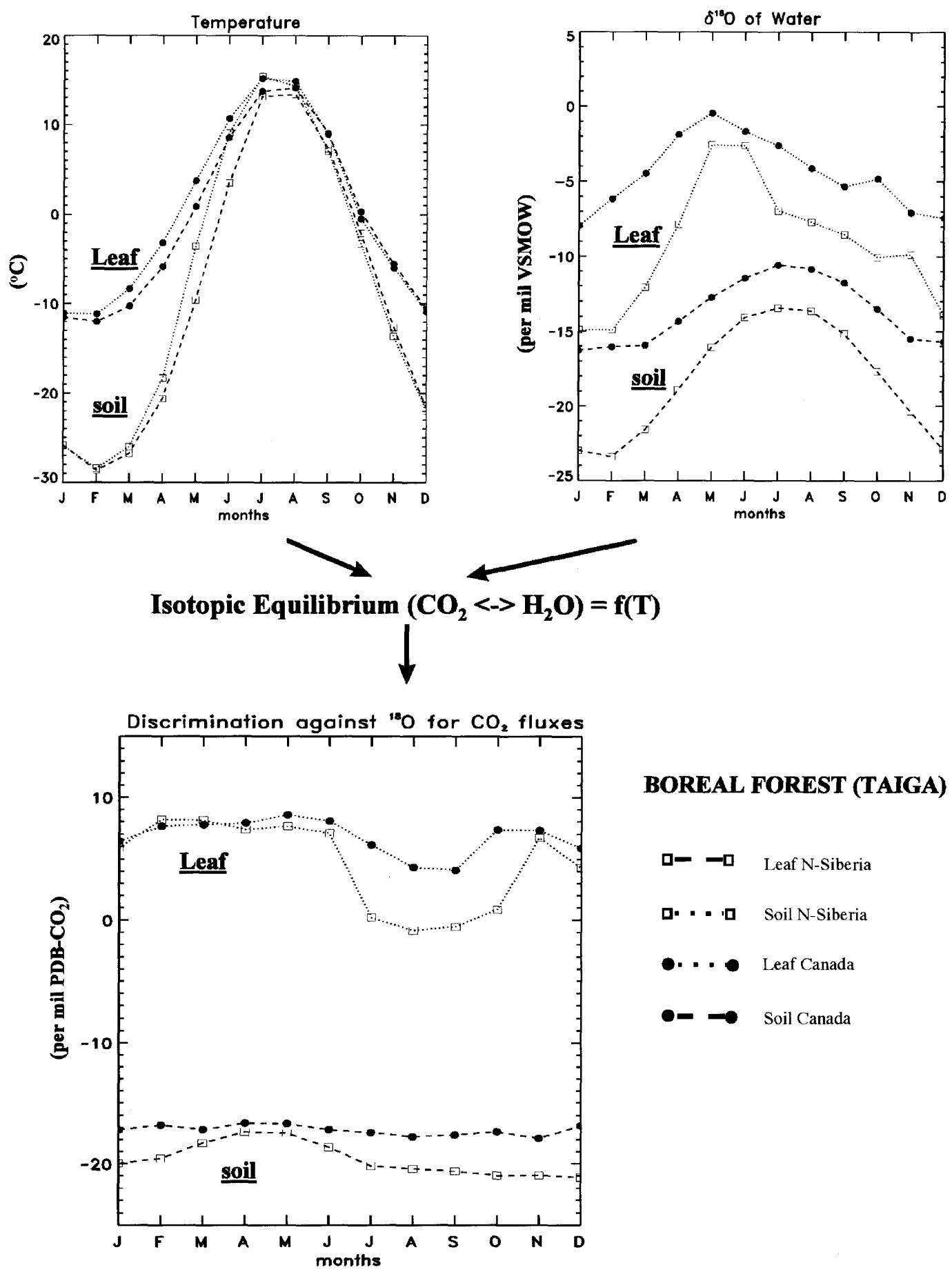

Fig. 10. Discrimination against ${ }^{18} \mathrm{O}$ compared to ${ }^{16} \mathrm{O}$ for $\mathrm{CO}_{2}$ fluxes (lower graph, same as upper left graph Fig. 9) associated with the net assimilation of carbon during photosynthesis (dotted lines) and with the release of carbon through respiration (dashed lines) the northern Siberian taiga and for the Canadian taiga (regions 4 and 2, respectively, Fig. 5). Discrimination by photosynthesis (respectively, respiration) results from a combination of the $\delta^{18} \mathrm{O}$ of the leaf water (soil surface moisture) with the leaf temperature (soil temperature) (see eq. (A1) in Appendix). 
Southern Site $\left(53.1^{\circ} \mathrm{N}, \mathbf{1 0 5 . 5}^{\circ} \mathrm{W}\right)$

Northern Site $\left(55.5^{\circ} \mathrm{N}, 97.5^{\circ} \mathrm{W}\right)$
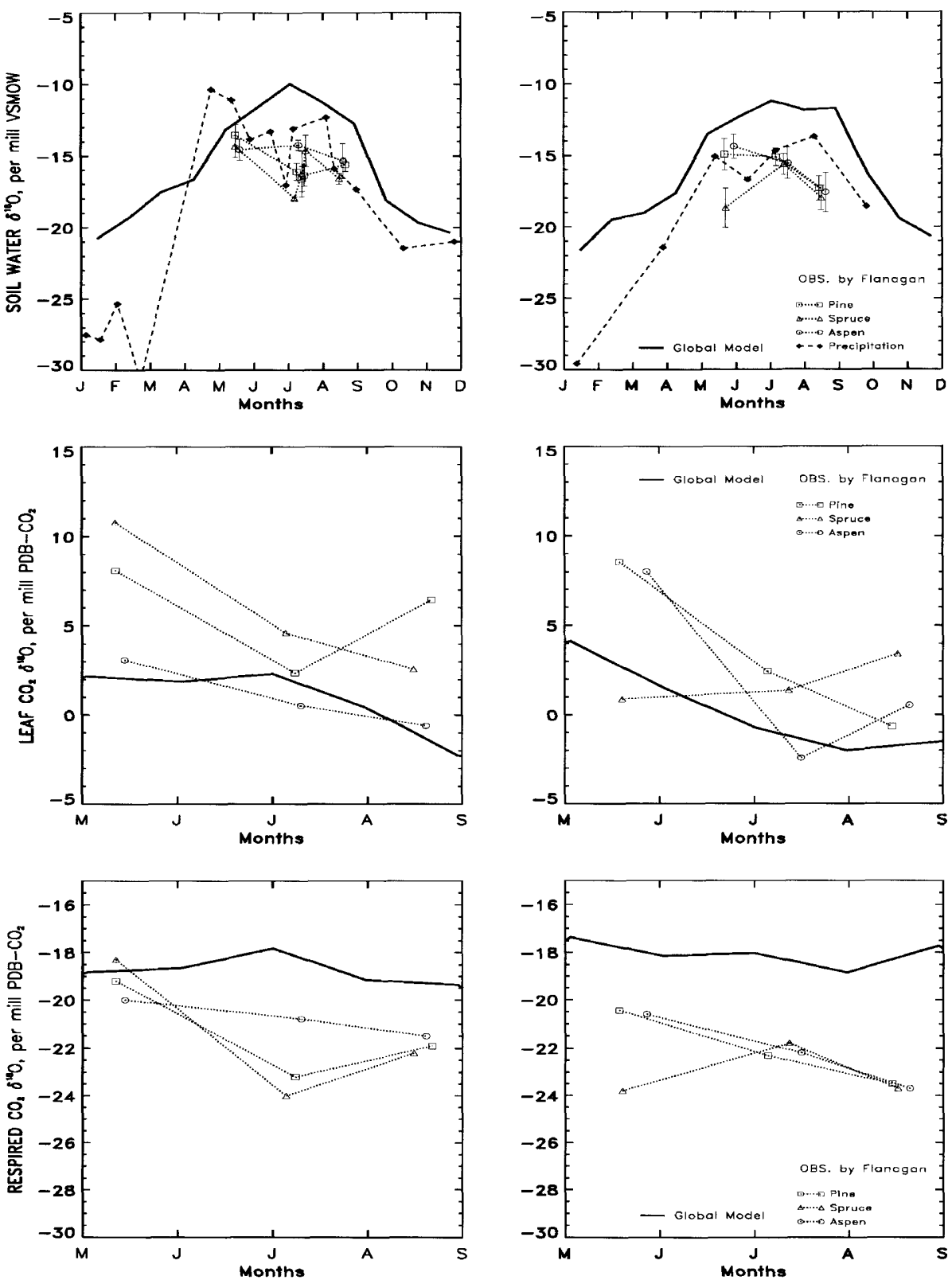

Fig. 11. $\delta^{18} \mathrm{O}$ of soil surface moisture (together with precipitation), of retrodiffused leaves $\mathrm{CO}_{2}$ and of soils respired $\mathrm{CO}_{2}$ simulated at two locations in the Canadian boreal forest (taiga) compared with the measurements of Flanagan during the BOREAS campaign, for the three dominant tree species. Observations for leaf $\delta^{18} \mathrm{O}$ and soil $\delta^{18} \mathrm{O}$ in $\mathrm{CO}_{2}$ are inferred from effective measurements of leaf water $\delta^{18} \mathrm{O}$ (respectively stem water $\delta^{18} \mathrm{O}$ which is an estimate for soil surface moisture $\delta^{18} \mathrm{O}$ ) only during the day for photosynthesis, assuming complete isotopic equilibrium between $\mathrm{CO}_{2}$ and $\mathrm{H}_{2} \mathrm{O}$ in the chloroplast (at the soil surface). Error bars ( \pm one standard deviation for 5 samples) are overplot for observed soil moisture $\delta^{18} \mathrm{O}$. 
more depleted in ${ }^{18} \mathrm{O}$ ). This points out the very important role of $h$ in predicting the $\delta^{18} \mathrm{O}$ of leaf water and hence the overall effect of photosynthesis in the global cycle of $\mathrm{C}^{18} \mathrm{O}^{16} \mathrm{O}$.

- $\delta^{18} \mathrm{O}$ of $\mathrm{CO}_{2}$ fluxes (see (eq. (A3)). The modeled $\delta^{18} \mathrm{O}$ of leaf exchanged $\mathrm{CO}_{2}$ roughly matches the observations with nevertheless too low values $(-3 \%$ and $-2 \%$ on average at SSA and NSA respectively, Fig. 11) which follows from the too low leaf water $\delta^{18} \mathrm{O}$ as pointed out above. Generally, there is an overall decrease in $\delta^{18} \mathrm{O}$ of $\mathrm{CO}_{2}$ retrodiffused from leaves over the course of the growing season at NSA and SSA, both in the data and in the model. The modeled $\delta^{18} \mathrm{O}$ of soil respired $\mathrm{CO}_{2}$ is almost constant throughout the growing season (Fig. 11), which is also the case for the values inferred by Flanagan. These latter values are predictions using the measured stem water $\delta^{18} \mathrm{O}$ as a proxy for soil water $\delta^{18} \mathrm{O}$ and the same fractionation factor $\left(\varepsilon_{\mathrm{s}}\right)$ as in our model. This agreement supports the important result shown in the previous section regarding the phase of $\delta^{18} \mathrm{O}$ in $\mathrm{CO}_{2}$ due to respiration. However, the modeled $\delta^{18} \mathrm{O}$ of the soil $\mathrm{CO}_{2}$ flux is less negative on average by $3.3 \%$ compared to the data, due to a clear overestimate of the GISS model precipitation $\delta^{18} \mathrm{O}$ as pointed out above. Note, that we use here stem water $\delta^{18} \mathrm{O}$ measurements (i.e., water taken up in the root layer) as a proxy of soil moisture $\delta^{18} \mathrm{O}$ not accounting for any additional evaporative enrichment of the surface soil moisture, an effect that could be further enhanced in the presence of mosses on the forest floor as discussed by Flanagan et al. (1997).

As a conclusion of this brief comparison, approximating the $\delta^{18} \mathrm{O}$ of soil moisture in the soil profile (at root depth) by the $\delta^{18} \mathrm{O}$ of meteoric water seems valid. Also, correcting the modeled output for $\delta^{18} \mathrm{O}$ of leaf retrodiffused $\mathrm{CO}_{2}$ and respired $\mathrm{CO}_{2}$, by the amount determined above in summer $(+3 \%)$ at two sites studied during BOREAS, would increase the isotopic seasonal signal both for photosynthesis and respiration. But the overall biospheric effect on the $\delta^{18} \mathrm{O}$ in atmospheric $\mathrm{CO}_{2}$ would remain nearly the same.

\section{Conclusion}

Using a global 3-D transport Model (TM2), we have in this study separated the contribution of different regions of the globe (as defined in Fig. 5) to the seasonal and latitudinal variations of $\delta^{18} \mathrm{O}$ in atmospheric $\mathrm{CO}_{2}$. We found a good agreement between our model output and the observations both for the amplitude and the phase of the $\delta^{18} \mathrm{O}$ seasonal cycle. The large seasonality at high northern latitudes appears to be mainly due to the respiratory flux of all extra-tropical ecosystems. This result is very different than for $\mathrm{CO}_{2}$ only, where the relative contributions of photosynthesis and respiration to the overall seasonal cycle are similar. Geographically, the exchange of $\mathrm{CO}_{2}$ with the northern Siberian taiga (mainly the respiration flux) drives half of the $\delta^{18} \mathrm{O}$ seasonal variations at remote "background" stations. This domination comes from lower values of $\delta^{18} \mathrm{O}$ in meteoric water and a stronger seasonality in the $\mathrm{CO}_{2}$ fluxes. Both of these characteristics result from the more interior continental location of Siberia compared to the other land regions and its more drastic climate.

The results derived in this paper need nevertheless to be more widely validated against field measurements (as we briefly did with the BOREAS campaign) and confirmed with the use of other global models. Errors on the major parameters such as the isotopic content of the precipitation and the ${ }^{18} \mathrm{O}$ enrichment of leaf water and surface soil moisture compared to ground water, need also to be better quantified. As an application of this "tagging" approach there is a potential to derive separately optimal values for the assimilation of the respiration fluxes of large ecosystems, using an "inverse technique" as in Enting et al. (1993). This could be achieved by combining the $\delta^{18} \mathrm{O}$ and $\mathrm{CO}_{2}$ data from the global sampling networks. Also based on the fact that the $\delta^{18} \mathrm{O}$ signal resulting from the northern ecosystems is more sensitive to the respiration flux (and to the assimilation) than to the meteoric water $\delta^{18} \mathrm{O}$ as pointed out above, interannual variations in atmospheric $\delta^{18} \mathrm{O}$ could be investigated in the same way.

\section{Acknowledgements}

We thank G. Hoffmann and P. Monfray for helpful discussion on this work, the people from the Institute for Arctic and Alpine Research at the University of Colorado (CU) and from the Centrum voor Isotopen Onderzoek (CIO) who 
made the isotopic analysis of the NOAA/CMDL flasks and the Scripps flasks, respectively. We thank the Cape Grim Baseline Air Pollution Station, the Australian Antarctic Division, and the CSIRO's GASLAB for the Cape Grim and South Pole data. Special thanks to L. B. Flanagan for providing isotopic data from two sites of the BOREAS experiment. The French Programme National d'Etude de la Dynamique du Climat and Commissariat à l'Energie Atomique funded this work. Support is also provided by the EC ESCOBA project, PNEDC-France. Denning was supported by the US National Science Foundation, grant number ATM-9711616.

\section{Appendix: Equations and symbols}

\begin{tabular}{|c|c|}
\hline$A$ & net rate of $\mathrm{CO}_{2}$ assimilation \\
\hline$F_{\text {resp }}$ & $\begin{array}{l}\mathrm{CO}_{2} \text { released by soil and plant } \\
\text { respiration }\end{array}$ \\
\hline$F_{\mathrm{ao}}$ & gross flux of $\mathrm{CO}_{2}$ into the ocean \\
\hline$F_{\text {oa }}$ & $\begin{array}{l}\text { gross flux of } \mathrm{CO}_{2} \text { out of the } \\
\text { ocean }\end{array}$ \\
\hline$F_{\text {fuel }}$ & $\begin{array}{l}\mathrm{CO}_{2} \text { released from fossil fuel } \\
\text { combustion }\end{array}$ \\
\hline$F_{\text {def }}$ & $\begin{array}{l}\text { net flux of } \mathrm{CO}_{2} \text { from } \\
\text { deforestation }\end{array}$ \\
\hline$\alpha_{\text {equ }}$ & $\begin{array}{l}\text { isotopic equilibration factor for } \\
\mathrm{CO}_{2} \text { with respect to } \mathrm{H}_{2} \mathrm{O} \\
\left(1+\varepsilon_{\text {equ }}\right)\end{array}$ \\
\hline$\varepsilon_{\mathrm{s}}$ & $\begin{array}{l}\text { fractionation factor for } \mathrm{CO}_{2} \\
\text { diffusion out of soil }(-8.8 \%)\end{array}$ \\
\hline$\varepsilon_{1}$ & $\begin{array}{l}\text { fractionation factor for } \mathrm{CO}_{2} \\
\text { diffusion into/out of the leaves } \\
(-7.4 \% 0)\end{array}$ \\
\hline$\varepsilon_{\mathrm{w}}$ & $\begin{array}{l}\text { fractionation factor for } \mathrm{CO}_{2} \\
\text { during dissolution and diffusion } \\
\text { in water }\end{array}$ \\
\hline$\varepsilon_{\text {vap }-1}^{\mathrm{w}}$ & $\begin{array}{l}\text { proportional depression factor of } \\
\text { water vapor of } \mathrm{H}_{2}^{18} \mathrm{O} \text { compared } \\
\text { to } \mathrm{H}_{2}^{16} \mathrm{O}\end{array}$ \\
\hline$\varepsilon_{\mathbf{k}}^{\mathbf{w}}$ & $\begin{array}{l}\text { kinetic fractionation against } \mathrm{H}_{2}^{18} \mathrm{O} \\
\text { compared to } \mathrm{H}_{2}^{16} \mathrm{O} \text { during } \\
\text { diffusion in the air }\end{array}$ \\
\hline$\delta_{1}^{\mathrm{w}}$ & $\begin{array}{l}{ }^{18} \mathrm{O} /{ }^{16} \mathrm{O} \text { ratio of chloroplast water } \\
\text { relative to VSMOW }\end{array}$ \\
\hline$\delta_{\mathrm{s}}^{\mathrm{w}}$ & $\begin{array}{l}{ }^{18} \mathrm{O} /{ }^{16} \mathrm{O} \text { ratio of ground water } \\
\text { relative to VSMOW }\end{array}$ \\
\hline$\delta_{\text {vap }}^{\mathrm{w}}$ & $\begin{array}{l}{ }^{18} \mathrm{O} /{ }^{16} \mathrm{O} \text { ratio of water vapor } \\
\text { above the canopy relative to } \\
\text { VSMOW }\end{array}$ \\
\hline
\end{tabular}

\begin{tabular}{|c|c|}
\hline$\delta_{\mathrm{s}}$ & $\begin{array}{l}{ }^{18} \mathrm{O} /{ }^{16} \mathrm{O} \text { ratio of } \mathrm{CO}_{2} \text { in isotopic } \\
\text { equilibrium with soil moisture } \\
\text { relative to } \mathrm{PDB}-\mathrm{CO}\end{array}$ \\
\hline$\delta_{1}$ & $\begin{array}{l}{ }^{18} \mathrm{O} /{ }^{16} \mathrm{O} \text { ratio of } \mathrm{CO}_{2} \text { in isotopic } \\
\text { equilibrium with chloroplast } \\
\text { water relative to } \mathrm{PDB}-\mathrm{CO}_{2}\end{array}$ \\
\hline$\delta_{\mathrm{o}}$ & $\begin{array}{l}{ }^{18} \mathrm{O} /{ }^{16} \mathrm{O} \text { ratio of } \mathrm{CO}_{2} \text { in isotopic } \\
\text { equilibrium with sea-water } \\
\text { relative to } \mathrm{PDB}-\mathrm{CO}_{2}\end{array}$ \\
\hline$\delta_{\mathrm{f}}$ & $\begin{array}{l}{ }^{18} \mathrm{O} /{ }^{16} \mathrm{O} \text { ratio of } \mathrm{CO}_{2} \text { produced } \\
\text { by burning relative to } \mathrm{PDB}-\mathrm{CO}_{2}\end{array}$ \\
\hline$\delta_{\mathrm{a}}$ & $\begin{array}{l}{ }^{18} \mathrm{O} /{ }^{16} \mathrm{O} \text { ratio of atmospheric } \mathrm{CO}_{2} \\
\text { relative to } \mathrm{PDB}-\mathrm{CO}_{2}\end{array}$ \\
\hline$\delta_{\mathrm{bg}}$ & $\begin{array}{l}{ }^{18} \mathrm{O} /{ }^{16} \mathrm{O} \text { ratio of "background" } \\
\text { atmospheric } \mathrm{CO}_{2} \text { relative to } \\
\mathrm{PDB}-\mathrm{CO}_{2}(0.0 \%)\end{array}$ \\
\hline$\delta_{i}$ & $\begin{array}{l}\text { modeled }{ }^{18} \mathrm{O} /{ }^{16} \mathrm{O} \text { ratio of } \\
\text { atmospheric } \mathrm{CO}_{2} \text { corresponding } \\
\text { to the only source/sink of } \mathrm{CO}_{2} \\
\text { relative to region (or process) } \\
\text { number } i\end{array}$ \\
\hline$\delta_{i}$-anomalies & $\begin{array}{l}\text { specific incremental change of } \\
\text { atmospheric }{ }^{18} \mathrm{O} /{ }^{16} \mathrm{O} \text { ratio due to } \\
\text { the incremental change in } \mathrm{CO}_{2} \\
\text { concentration }\end{array}$ \\
\hline$\Delta_{\mathrm{A}}$ & $\begin{array}{l}\text { discrimination against }{ }^{18} \mathrm{O} \\
\text { (compared to }{ }^{16} \mathrm{O} \text { ) during net } \\
\mathrm{CO}_{2} \text { assimilation by } \\
\text { photosynthesis (Farquhar et al., } \\
\text { 1993) }\end{array}$ \\
\hline$\Delta_{\mathrm{R}}$ & $\begin{array}{l}\text { discrimination against }{ }^{18} \mathrm{O} \\
\text { (compared to }{ }^{16} \mathrm{O} \text { ) for } \mathrm{CO}_{2} \\
\text { emitted during respiration }\end{array}$ \\
\hline $\mathrm{PDB}-\mathrm{CO}_{2}$ & $\begin{array}{l}\mathrm{CO}_{2} \text { derived from pee dee } \\
\text { belemnite calcite }\end{array}$ \\
\hline$M_{\mathrm{a}}$ & $\begin{array}{l}\text { number of moles of } \mathrm{CO}_{2} \text { in the } \\
\text { atmosphere }\end{array}$ \\
\hline$C_{\mathrm{a}}$ & atmospheric $\mathrm{CO}_{2}$ concentration \\
\hline$C_{\mathrm{chl}}$ & $\begin{array}{l}\mathrm{CO}_{2} \text { concentration inside the } \\
\text { chloroplast }\end{array}$ \\
\hline$C_{i}$ & $\begin{array}{l}\text { modeled atmospheric } \mathrm{CO}_{2} \\
\text { concentration corresponding to } \\
\text { the only source/sink of } \mathrm{CO}_{2} \\
\text { relative to region (or process) } \\
\text { number } i\end{array}$ \\
\hline$h$ & $\begin{array}{l}\text { relative humidity inside the } \\
\text { canopy }\end{array}$ \\
\hline
\end{tabular}

Isotopic equilibrium reaction between $\mathrm{CO}_{2}$ and $\mathrm{H}_{2} \mathrm{O}$. In nature, when reaction (A1) occurs, $\mathrm{H}_{2} \mathrm{O}$ is much more abundant than $\mathrm{CO}_{2}$ which implies 
that $\delta^{18} \mathrm{O}$ of $\mathrm{CO}_{2}$ is entirely determined by that of water. The equilibration factor $\alpha_{\text {equ }}$ is function of the temperature (Brenninkmeijer et al., 1983) and there is an enrichment of ${ }^{18} \mathrm{O}$ in $\mathrm{CO}_{2}$ compared to $\mathrm{H}_{2} \mathrm{O}: \alpha_{\text {equ }}=1+\varepsilon_{\text {equ }}$ and $\varepsilon_{\text {equ }}=41.11 \%$ at $25^{\circ} \mathrm{C}$.

$$
\mathrm{C}^{16} \mathrm{O}^{16} \mathrm{O}+\mathrm{H}_{2}^{18} \mathrm{O} \leftrightarrow \mathrm{C}^{18} \mathrm{O}^{16} \mathrm{O}+\mathrm{H}_{2}^{16} \mathrm{O}
$$

with

$\alpha_{\text {equ }}=\frac{\left({ }^{18} \mathrm{O} /{ }^{16} \mathrm{O}\right)_{\mathrm{CO}_{2} \text { after equilibration }}}{\left({ }^{18} \mathrm{O} /{ }^{16} \mathrm{O}\right)_{\text {reacting } \mathrm{H}_{2} \mathrm{O}}}=f(T)$.

Isotopic enrichment of chloroplast water. The water at the site of evaporation within the leaf is enriched in ${ }^{18} \mathrm{O}$ compared to soil water. At steady state during photosynthesis, and for a constant leaf water volume, the $\delta^{18} \mathrm{O}$ of leaf water $\left(\delta_{1}^{\mathrm{w}}\right)$ is given by (Craig and Gordon, 1965)

$\delta_{1}^{\mathrm{w}}=\varepsilon_{\mathrm{vap}-1}^{\mathrm{w}}+(1-h)\left(\delta_{\mathrm{s}}^{\mathrm{w}}-\varepsilon_{\mathrm{k}}^{\mathrm{w}}\right)+h \delta_{\text {vap }}^{\mathrm{w}}$.

Global mass balance for ${ }^{18} \mathrm{O}$ in atmospheric $\mathrm{CO}_{2}$. The mass balance is expressed in $\delta$-scale as defined by Farquhar et al. (1993). Photosynthesis and respiration (terms in bold) as well as air-sea exchange, fossil fuel burning and deforestation are included.

$$
\begin{aligned}
M_{\mathrm{a}} \frac{\mathrm{d} \delta_{\mathrm{a}}}{\mathrm{d} t}= & A \Delta_{\mathrm{A}}+F_{\text {resp }} \Delta_{\mathrm{R}}+\varepsilon_{\mathrm{w}}\left(\mathrm{F}_{\mathrm{ao}}-F_{\mathrm{oa}}\right) \\
& +F_{\mathrm{oa}}\left(\delta_{\mathrm{o}}-\delta_{\mathrm{a}}\right)+F_{\text {fuel }}\left(\delta_{\mathrm{f}}-\delta_{\mathrm{a}}\right) \\
& +F_{\text {def }}\left(\delta_{\mathrm{f}}-\delta_{\mathrm{a}}\right)
\end{aligned}
$$

with

$\Delta_{\mathrm{A}}=-\varepsilon_{1}+\frac{C_{\mathrm{chl}}}{C_{\mathrm{a}}-C_{\mathrm{chl}}}\left(\delta_{1}-\delta_{\mathrm{a}}\right)$

$\Delta_{\mathrm{R}}=\delta_{\mathrm{s}}-\delta_{\mathrm{a}}+\varepsilon_{\mathrm{s}}$.

\section{REFERENCES}

Bariac, T. 1988. La transpiration des plantes terrestres et les isotopes stables de l'eau $\left({ }^{18} \mathrm{O},{ }^{2} \mathrm{H}\right)$ : conséquences pour le tracage isotopique des eaux naturelles. Bull. Soc. Géol. France 4, 187-192.

Brenninkmeijer, C. A. M., Kraft, P. and Mook, W. G. 1983. Oxygen isotope fractionation between $\mathrm{CO}_{2}$ and $\mathrm{H}_{2}$ O. Isotope Geoscience 1, 181-190.

Ciais, P. and Meijer, H. 1998. The ${ }^{18} \mathrm{O} /{ }^{16} \mathrm{O}$ isotope ratio and its role in global carbon cycle research. In: Stable isotopes: integration of biological, ecological and geochemical processes (ed. H. Griffiths), pp.409-431. BIOS.

Ciais, P., Tans, P. P., White, J. W. C., Trolier, M., Francey, R. J., Berry, J. A., Randall, D. A., Sellers, P. J., Collatz, J. G. and Schimel, D. S. 1995. Partitioning of ocean and land uptake of $\mathrm{CO}_{2}$ as inferred by $\delta^{13} \mathrm{C}$ measurements from the NOAA climate monitoring and diagnostics laboratory global air sampling network. J. Geophys. Res. 100, 5051-5070.

Ciais, P., Denning, A. S., Tans, P. P., Berry, J. A., Randall, D. A., Collatz, G. J., Sellers, P. J., White, J. W., Trollier, M., Meijer, H. A. J., Francey, R. J., Monfray, P. and Heimann, M. 1997a. A three-dimensional synthesis study of $\delta^{18} \mathrm{O}$ in atmospheric $\mathrm{CO}_{2}$, Part I: Surface fluxes. J. Geophys. Res. 102, 5857-5872.

Ciais, P., Tans, P. P., Denning, A. S., Francey, R. J., Trollier, M., Meijer, H. J., White, J. W., Berry, J. A., Randall, D. A., Collatz, J. J. G., Sellers, P. J., Monfray, P. and Heimann, M. 1997b. A three-dimensional synthesis study of $\delta^{18} \mathrm{O}$ in atmospheric $\mathrm{CO}_{2}$, Part II: Simulations with the TM2 transport model. J. Geophys. Res. 102, 5873-5883.

Craig, H. and Gordon, A. 1965. Deuterium and
Oxygen-18 variations in the ocean and the marine atmosphere. In: Stable isotopes in oceanic studies and paleotemperatures (ed. Laboratory of Geology and Nuclear Science), Pisa, Italy.

Denning, A. S., Collatz, G. J., Zhang, C., Randall, D. A., Berry, J. A., Sellers, P. J., Colello, G. D. and Dazlich, D. A. 1996. Simulations of terrestrial carbon metabolism and atmospheric $\mathrm{CO}_{2}$ in a general circulation model, Part 1: Surface carbon fluxes. Tellus 48B, 521-542.

Enting, I. G., Trudinger, C. M., Francey, R. J. and Granek, H. 1993. Synthesis inversion of atmospheric $\mathrm{CO}_{2}$ using the GISS tracer transport model. Tech. Rep. 29, CSIRO Div. Atmos. Res., Australia.

Farquhar, G. D., Lloyd, J., Taylor, J. A., Flanagan, L. B., Syvertsen, J. P., Hubick, K. T., Wong, S. and Ehleringer, J. R. 1993. Vegetation effects on the isotope composition of oxygen in atmospheric $\mathrm{CO}_{2}$. Nature 363, 439-443.

Flanagan, L. B. and Varney, G. T. 1995. Influence of vegetation and soil $\mathrm{CO}_{2}$ exchange on the concentration and stable oxygen isotope ratio of atmospheric $\mathrm{CO}_{2}$ within a Pinus resinosa canopy. Oecologia 101, 37-44.

Flanagan, L. B., Brooks, J. R., Varney, G. T. and Ehleringer, F. R. 1997. Discrimination against $\mathrm{C}^{18} \mathrm{O}^{16} \mathrm{O}$ during photosynthesis and the oxygen isotope ratio of respired $\mathrm{CO}_{2}$ in boreal forest ecosystems. Global Biogeoch. Cycl. 11, 83-98.

Francey, R. J. and Tans, P. 1987. Latitudinal variation in oxygen-18 of atmospheric $\mathrm{CO}_{2}$. Nature 327, 495-497.

Francey, R. J., Robbins, F. J., Allison, C. E. and Richards, 
N. G. 1990. The CSIRO global survey of $\mathrm{CO}_{2}$ stable isotopes. In: Baseline atmospheric research program (Australia) 1988 (eds. S. R. Wilson and G. P. Ayers). Ayers, Department of Administrative Services/Bureau of Meteorology and CSIRO Division of Atmospheric Research.

Francey, R. J., Tans, P. P., Allison, C. E., Enting, I. G., White, J. W. C. and Trolier, M. 1995. Changes in oceanic and carbon uptake since 1982. Nature 373, 326-330.

Gemery, P. A., Trolier, M. and White, J. W. C. 1996. Oxygen isotope exchange between carbon dioxide and water following atmospheric sampling using glass flasks. J. Geophys. Res. 101, 14414-14420.

Haszpra, L. 1995. Carbon dioxide concentration measurements at a rural site in Hungary. Tellus 47B, 17-22.

Heimann, M. 1995. The global atmospheric tracer model TM2: model description and user manual. Tech. Rep. 10, Max Planck Institut für Meteorologie, Hamburg.

Heimann, M. and Keeling, C. D. 1989. A three-dimensional model of atmospheric $\mathrm{CO}_{2}$ transport based on observed winds (2). Model description and simulated tracer experiments. In: Aspects of climate variability in the Pacific and the Western Americas. Geophysical Monograph 55 (ed. P. D. H.), 237-275. AGU.

Hesterberg, R. and Siegenthaler, U. 1991. Production and stable isotopic composition of $\mathrm{CO}_{2}$ in a soil near Bern, Switzerland. Tellus 43B, 197-205.

IAEA, 1992. Statistical treatment of data on environmental isotopes in precipitation. Tech. Rep. 331, I.A.E.A.

Jacob, H. and Sonntag, C. 1991. An 8-year record of the seasonal variation of ${ }^{2} \mathrm{H}$ and ${ }^{18} \mathrm{O}$ in atmospheric water vapour and precipitation at Heidelberg, Germany. Tellus 43B, 291-300.

Jouzel, J., Russell, G. L., Suozzo, R. J., Koster, R. D., White, J. W. C. and Broecker, W. S. 1987. Simulations of the $\mathrm{HDO}$ and $\mathrm{H}_{2}^{18} \mathrm{O}$ atmospheric cycles using the NASA/GISS general circulation model: The seasonal cycle for present-day conditions. J. Geophys. Res. 92 , 14739-14760.

Kaminski, T., Giering, R. and Heimann, M. 1996. Sensitivity of the seasonal cycle of $\mathrm{CO}_{2}$ at remote monitoring stations with respect to seasonal surface exchange fluxes determined with the adjoint of an atmospheric transport model. Phys. and Chem. of the Earth 21, 457-462.

Keeling, C. D. 1958. The concentrations and isotopic abundances of atmospheric carbon dioxide in rural areas. Geochim. Cosmochim. Acta 13, 322 334.

Keeling, C. D., Bacastow, R. B., Carter, A. F., Piper, S. C., Whorf, T. P., Heimann, M., Mook, W. G. and Roeloffzen, H. A. 1989. A three-dimensional model of atmospheric $\mathrm{CO}_{2}$ transport based on observed winds (1). Analysis of observational data. In: Aspects of climate variability in the Pacific and the Western Americas. Geophysical Monograph 55 (ed. P. D. H.), 165-236. AGU.

Keeling, C. D., Whorf, T., Wahlen, M. and Van der Plicht, J. 1995. Interannual extremes in the rate of rise of atmospheric carbon dioxide since 1980. Nature 375, 666-670.

Louis, J. F. 1979. A parametric model of vertical eddy fluxes in the atmosphere. Boundary Layer Meteorology 17, 187-202.

Mathieu, R. and Bariac, T. 1996. A numerical model for the simulation of stable isotope profiles in drying soils. J. Geophys. Res. 101, 12685-12696.

Miranda, A. C., Miranda, H. S., Lloyd, J., Grace, J., Francey, R. J., McIntyre, J. A., Riggan, P., Lockwood, R. and Brass, J. 1994. Fluxes of carbon, water and energy over Brazilian cerrado: An analysis using eddy covariance and stable isotopes. Plant Cell Envir. 20, 315-328.

Peylin, P., Ciais, P., Tans, P. P., Six, K., Berry, J. A. and Denning, A. S. $1996 .{ }^{18} \mathrm{O}$ in atmospheric $\mathrm{CO}_{2}$ simulated by a 3-D transport model. A sensitivity study to vegetation and soil fractionation factors. Phys. and Chem. of the Earth 21, 463-469.

Ramonet, M. 1994. Variabilité du $\mathrm{CO}_{2}$ atmosphérique en région australes: Comparaison modèle et mesures. $\mathrm{PhD}$ thesis, Univ. Paris VII, 4 Place de Jussieu, 75006 Paris.

Randall, D. A., Dazlich, D. A., Zhang, C., Denning, A. S., Sellers, P. J., Tucker, C. J., Bounoua, L., Berry, J. A., Collatz, G. J., Field, C. B., Los, S. O., Justice, C. O. and Fung, I. 1996. A revised land surface parameterization (SiB2) for atmospheric GCMs. Part III: The greening of the Colorado State University general circulation model. J. Climate 9, 738-763.

Rasmussen, J. L. 1996. Climate Monitoring and Diagnostics Laboratory: Summary report 1994-95. Tech. Rep. 23, US Department of Commerce, National Oceanic and Atmospheric Administration Environmental Research Laboratories.

Reed, M. and Graham, D. 1981. Progress in Phytochemistry 7, 47-94. Interscience Publisher, London.

Rozanski, K., L., A.-A. and R., G. 1992. Relation between long-term trends of oxygen-18 isotope composition of precipitation and climate. Science 258, 981-985.

Sellers, P., Hall, F., Margolis, H., Kelly, B., Baldocchi, D., den Hartog, G., Cihlar, J., Ryan, M., Goodison, B., Crill, P., Ranson, K., Lettenmaier, D. and Wichland, D. 1995. The boreal ecosystem-atmosphere study (BOREAS): an overview and early results from the 1994 field year. Bull. Am. Meteorol. Soc. 76, 1549-1577.

Sellers, P. J., Los, S. O., Tucker, C. J., Justice, C. O. Dazlich, D. A., Collatz, G. J. and Randall, D. A. 1996a. A revised land surface parameterization ( $\mathrm{SiB} 2$ ) for atmospheric GCMs. Part II. The generation of global fields of terrestrial biophysical parameters from satellite data. J. Climate 9, 706-737.

Sellers, P. J., Randall, D. R., Collatz, G. J., Berry, J. A., Field, C. B., Dazlich, D. A., Zhang, C., Collelo, G. D. and Bounoua, L. 1996b. A revised land surface parameterization (SiB2) for atmospheric GCMs. Part I: Model formulation. J. Climate 9, 676-705.

Tans, P. 1998. Oxygen isotopic equilibration between carbon dioxide and water in soils. Tellus 50, 163-178. 
Thiemens, M. H. and Jackson, T. 1991. Oxygen isotope fractionation in stratospheric $\mathrm{CO}_{2}$. Geophys. Res. Letters 18, 669-672.

Thoning, K. W., Tans, P. P. and Komhyr, W. D. 1994. Atmospheric carbon dioxide at Mauna Loa Observatory 2. Analysis of the NOAA GMCC data, 1974-1985. J. Geophys. Res. 94, 8549-8565.

Tiedke, M. 1989. A comprehensive mass flux scheme for cumulus parameterization in large scale models. Monthly Weather Review 117, 1779-1800.

Trolier, M., White, J., Tans, P., Masarie, K. and Gemery, P. 1995. Monitoring the isotopic composition of atmospheric $\mathrm{CO}_{2}$ : measurements from the NOAA global air sampling network. J. Geophys. Res. 20, 25896-25916.
Wang, X.-F. and Yakir, D. 1995. Temporal and spatial variations in the oxygen-18 content of leaf water in different plant species. Plant, Cell and Envir. 18, $1377-1385$.

White, J. W. C. and Gedzelman, S. D. 1984. The isotopic composition of atmospheric water vapor and the concurrent meteorological conditions. J. Geophys. Res. 89, 4937-4939.

Yakir, D., Berry, J. A., Giles, L. and Osmond, C. B. 1994. Isotopic heterogeneity of water in transpiring leaves: identification of the component that controls the $\delta^{18} \mathrm{O}$ of atmospheric $\mathrm{O}_{2}$ and $\mathrm{CO}_{2}$. Plant, Cell and Envir. 17, 73-80. 